\title{
17. EOCENE AND OLIGOCENE CALCAREOUS NANNOFOSSILS FROM THE LABRADOR SEA, ODP LEG 105 1
}

\author{
John V. Firth ${ }^{2}$
}

\begin{abstract}
During Ocean Drilling Program (ODP) Leg 105, a thick sequence of lower Eocene to lower Oligocene sediments was recovered from Hole 647A in the southern Labrador Sea. These sediments contain diverse, well-preserved, high-latitude calcareous nannofossil flora. The nannofossil biostratigraphy of the hole indicates the presence of a minor hiatus between Zones NP16 and NP17 in the upper middle Eocene and a barren interval separating Zones NP13 and NP15. Species abundance is highest within the lower to middle Eocene and starts to decline near the base of the upper Eocene. No major change in the nannoflora was observed across the Eocene/Oligocene boundary, although a slight decrease in species abundance was recorded. The Paleogene calcareous nannofossils of nearby DSDP Site 112 were reexamined and compared with those of Site 647. Several cores were reassigned to different nannofossil zones. The calcareous nannoflora are dominated by high-latitude indicative species and also exhibit a high diversity, which suggests the influence of more temperate water masses in this region during Eocene and Oligocene time. One new subspecies from the middle Eocene, Sphenolithus furcatolithoides labradorensis, is described.
\end{abstract}

\section{INTRODUCTION}

During Leg 105, 11 holes were drilled at three sites along a north-south transect from Baffin Bay to the southern Labrador Sea (Fig. 1) to study the Cenozoic paleoceanographic and tectonic histories of this high-latitude region. The third site, Site 647, was drilled on the south flank of the Gloria Drift, at $53^{\circ} 19.9^{\prime} \mathrm{N}$ and $45^{\circ} 15.7^{\prime} \mathrm{W}$, at a water depth of $3869 \mathrm{~m}$. Of the several objectives for Site 647 , two were concerned with the $\mathrm{Pa}$ leogene: (1) to recover a continuous Eocene-Oligocene, high-latitude sequence to study the climatic, biologic, and oceanographic changes across this important transition, and (2) to recover and date the oceanic crust to constrain tectonic models for the evolution of the Labrador Sea. Hole 647A was rotary cored to basement, where a thick sequence of lower upper Oligocene to middle Eocene biogenic claystones and clayey oozes (lithologic Unit III) and middle to lower Eocene claystones (lithologic Unit IV; see Site 647 chapter, Srivastava, Arthur, et al., 1987) was recovered.

This report documents the high-latitude Paleogene calcareous nannofossil assemblages from Hole 647A and establishes a biostratigraphy for the sediments based on these asssemblages. In addition, the results are compared with other high-latitude Paleogene sites from the Labrador Sea and North Atlantic basin. The standard zonation of Martini and Müller (1986) was used primarily, although the low-latitude zonation of Okada and Bukry (1980) also was used in one or two instances to augment the standard zones.

\section{METHODS}

Smear slides were prepared for each of the recovered samples, using Norland Optical Adhesive as the mounting medium. Slides were routinely scanned with a magnification of $980 \times$, and relative abundances of each species were recorded using the following scale:
A (abundant) $=10-100$ specimens/field of view,
$C$ (common) $=1-10$ specimens $/$ field of view,
$\mathrm{F}$ (few) $\quad=1$ specimen $/ 1-10$ fields of view,
$\mathrm{R}$ (rare) = $\quad 1$ specimen $/ 10-100$ fields of view,
$\mathrm{P}$ (present) $\quad=\mathrm{a}$ few specimens per slide

\footnotetext{
${ }^{1}$ Srivastava, S. P., Arthur, M., Clement, B., et al., 1989. Proc. ODP, Sci. Results, 105: College Station, TX (Ocean Drilling Program).

${ }^{2}$ Department of Geology, Florida State University, Tallahassee, FL 32306.
}

Preservation of calcareous nannofossils was recorded as follows:

$\mathrm{G}$ (good) = no dissolution or overgrowth,

$\mathrm{M}$ (moderate) $=$ slight to moderate dissolution or overgrowth,

$\mathrm{P}$ (poor) = considerable dissolution or overgrowth .

Selected samples were prepared for examination with a JEOL 840 scanning electron microscope (SEM). The following techniques were used to locate and photograph the same specimens under both light and scanning electron microscopy (Applegate and Bergen, 1988). Samples were cleaned through repeated gravity settling to remove clay-size particles. A rubber stamp was used to impart an ink grid on a round $(12 \mathrm{~mm}$ diameter) cover slip. The grid consisted of 25 squares, each $1 \mathrm{~mm}^{2}$ in size. Each square contained a letter in the center and was divided into four quadrants. A drop of suspended sample was placed on the cover slip and allowed to dry. The cover slip was then attached, sample side up, to a glass slide and placed under a $100 \times$ oil-immersion lens for photomicrography. The exact locations of photographed specimens were recorded, usually by a hand-drawn sketch. The cover slip was then removed, carefully immersed in xylene and/or ethyl alcohol to remove the immersion oil, and allowed to dry. The cover slip was attached to an SEM stub for examination under the SEM.

\section{BIOSTRATIGRAPHY}

\section{Oligocene}

Sample $105-647 \mathrm{~A}-14 \mathrm{R}-1,59-61 \mathrm{~cm}$, contains only rare, poorly preserved specimens of Reticulofenestra bisecta. The remaining samples from Core 105-647A-14R are barren of nannofossils. The presence of $R$. bisecta suggests that Sample 105-647A-14R$1,59-61 \mathrm{~cm}$, is of Oligocene age. However, these poorly preserved specimens may be reworked from older sediments. Lower Miocene radiolarians that occur in Core 105-647A-14R (Lazarus, this volume) indicate that the latter interpretation is correct.

Sediments of definite Oligocene age, containing common, moderately preserved $R$. bisecta, Cyclicargolithus abisectus, and C. floridanus first occur in Sample 105-647A-15R-1, 68-70 cm (Table 1). Rare specimens of Sphenolithus predistentus and $S$. distentus also occur in Samples 105-647A-15R-1, 68-70 cm, and 105-647A-15R-2, 66-68 cm, respectively. One specimen of Sphenolithus ciperoensis was found in Sample 105-647A-16R-3, 36$38 \mathrm{~cm}$ (Pl. 4, Figs. 5 and 6). This specimen has an uncharacteristically large base, but exhibits the "chevron" extinction pattern that distinguishes it from Sphenolithus distentus. The interval 


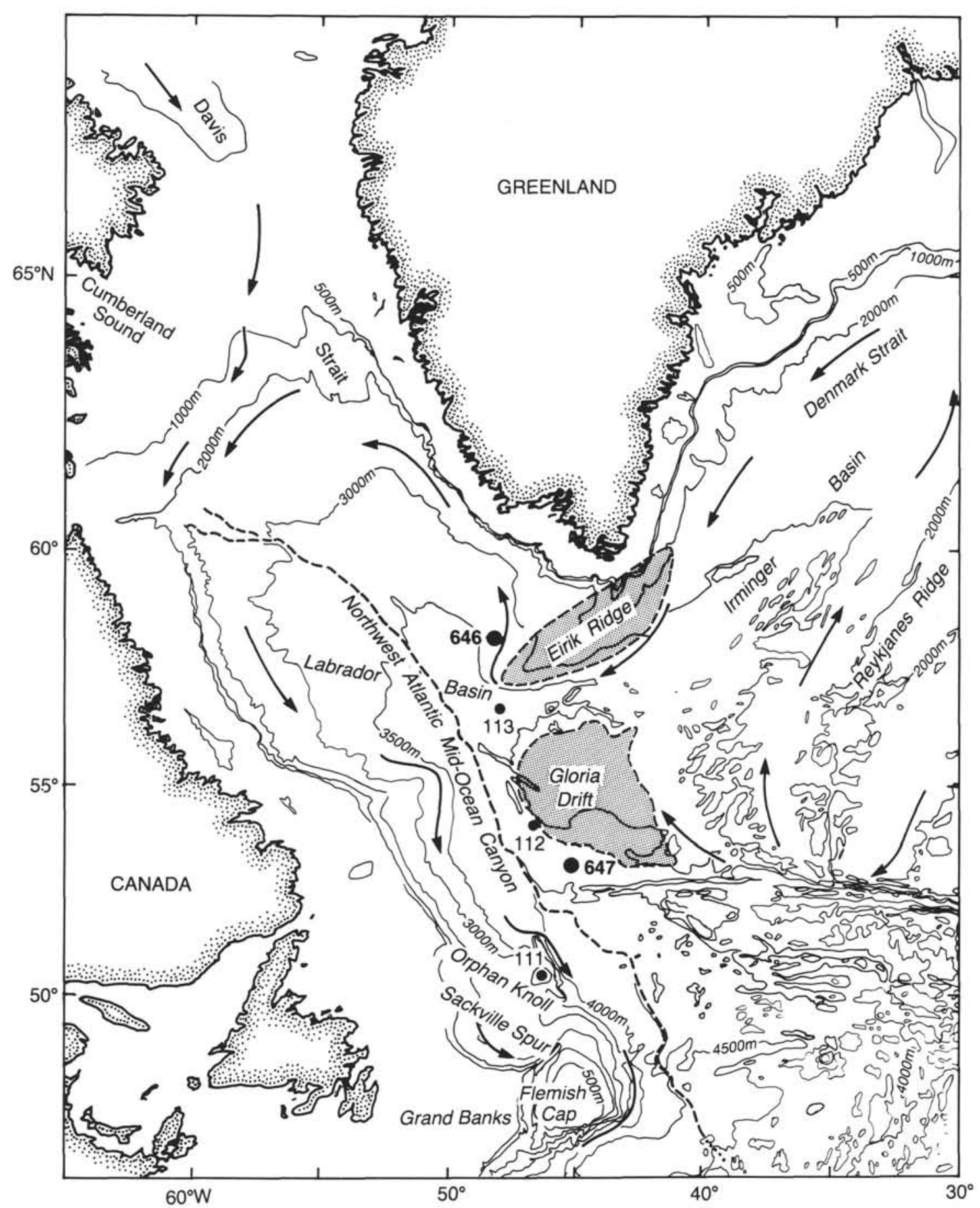

Figure 1. Location of ODP Site 647 and DSDP Site 112 in the Labrador Sea.

from Sample 105-647A-15R-1, 68-70 cm, to Sample 105-647A$16 \mathrm{R}-3,36-38 \mathrm{~cm}$, was assigned to Zone NP24. Because of the single occurrence of $S$. ciperoensis, the NP23/NP24 zonal boundary can be placed only tentatively between Sample 105-647A16R-3, 36-38 cm, and Section 105-647A-16R, CC. Rare specimens of Sphenolithus delphix and $S$. dissimilis occur as low as Samples 105-647A-19R-4, 14-16 cm, and 105-647A-19R-5, 25$27 \mathrm{~cm}$, respectively. These two species usually are found only in the upper Oligocene (Perch-Nielsen, 1985), which may indicate that the NP23/NP24 zonal boundary should be placed lower in Hole 647A.

The interval from Section 105-647A-16R, CC through Sample 105-647A-23R-1, 118-120 cm, lies between the occurrence of
S. ciperoensis and the highest consistent occurrence of Reticulofenestra umbilica in Sample 105-647A-23R-2, 110-112 cm, and can be assigned to Zone NP23. The assemblage is dominated by $R$. bisecta, C. abisectus, C. floridanus, and Coccolithus pelagicus, with rare to common Chiasmolithus altus and rare but consistently present Sphenolithus distentus and $S$. predistentus. A large number of Helicosphaera species occur in this zone, but they are mostly rare and scattered.

Rare, scattered occurrences of $R$. umbilica and Isthmolithus recurvus in Zone NP23 samples are attributed to reworking. This interpretation is supported by the rare occurrences of reworked Discoaster saipanensis, an Eocene marker species, in the same interval. 
Samples $105-647$ A-23R-2, 110-112 cm, to $105-647$ A-25R-5-1 61-63 cm, lie between the highest consistent occurrence of $R$. umbilica and the highest occurrence of Ericsonia formosa and are assigned to Zone NP22. Sphenolithus distentus has its lowest occurrence in the lower part of this zone. $R$. umbilica is rare to few in abundance through this zone and does not become a major component of the assemblage until sediments assigned to Zone NP21 are reached.

Samples 105-647A-27R-1, 52-53 cm, to 105-647A-30R-7, 17$19 \mathrm{~cm}$, contain Ericsonia formosa but do not contain Discoaster barbadiensis and thus were assigned to Zone NP21. The assemblage in this zone contains common to abundant $R$. umbilica, Reticulofenestra daviesii, Isthmolithus recurvus, $R$. bisecta, Coccolithus pelagicus, and Ericsonia fenestrata.

\section{Eocene}

The highest occurrence of $D$. barbadiensis in Sample 105$647 \mathrm{~A}-30 \mathrm{R}-7,48 \mathrm{~cm}$, is used to mark the top of the Eocene, although Discoaster barbadiensis and Discoaster saipanensis are both rare in the upper part of their range of occurrence (Table 2). Scattered occurrences of $D$. saipanensis above Sample 105647A-30R-7, $48 \mathrm{~cm}$, are interpreted as reworked. On the basis of benthic foraminifers (Kaminsky et al., this volume) and planktonic foraminifers (see Site 647 chapter, Srivastava, Arthur, et al., 1987) the Eocene/Oligocene boundary was placed slightly below that assigned on the basis of the nannofossils, near the base of Core 105-647A-30R.

Samples 105-647A-30R-7, $48 \mathrm{~cm}$, to 105-647A-46R-3, 33-35 $\mathrm{cm}$, contain Chiasmolithus oamaruensis, Isthmolithus recurvus, and Discoaster barbadiensis and thus were assigned to the upper Eocene (Zones NP18-NP20). The lowest occurrence of Isthmolithus recurvus coincides with that of Chiasmolithus oamaruensis (see "Comments," this chapter, for further discussion of this problem), while Sphenolithus pseudoradians does not occur in the section. Thus, the upper Eocene could not be subdivided on the basis of calcareous nannofossils. Cribrocentrum reticulatum, Reticulofenestra umbilica, Coccolithus pelagicus, and Reticulofenestra bisecta are the dominant species in this interval.

Samples $105-647 \mathrm{~A}-46 \mathrm{R}-4,101-103 \mathrm{~cm}$, to $105-647 \mathrm{~A}-47 \mathrm{R}-6$, $42-44 \mathrm{~cm}$, fall between the highest occurrence of Chiasmolithus solitus in Sample 105-647A-48R-1, 91-93 cm, and the lowest occurrence of Chiasmolithus oamaruensis and thus were assigned to Zone NP17 (Table 3). This zone is characterized by common Reticulofenestra umbilica, Coccolithus pelagicus, Chiasmolithus expansus, and common to abundant Cribrocentrum reticulatum. Reticulofenestra bisecta is rare to few throughout this zone and has its lowest occurrence just below the base of NP17 in Sample 105-647A-48R-3, 88-90 cm.

Zone NP17 is separated from Zone NP16 by one barren sample, 105-647A-47R, CC. Preservation is poor in adjacent samples above and below this barren sample. The highest occurrence of Chiasmolithus solitus and a marked increase upsection in the abundance of Chiasmolithus expansus coincide with this interval, which suggests the presence of an unconformity or a period of reduced sedimentation rate. This interpretation is supported by the extinction or disappearance of at least one benthic foraminifer species in this same interval (Kaminsky et al., this volume).

The highest occurrence of $C$. solitus in Sample 105-647A48R-1, 91-93 cm, marks the top of Zone NP16. The highest occurrence of the genus Nannotetrina can be used to approximate the NP15/NP16 boundary when the marker species, Rhabdosphaera gladius, is missing (Perch-Nielsen, 1985). Therefore, the base of Zone NP16 tentatively was placed just above the highest occurrence of Nannotetrina cristata in Sample 105-647A-57R, CC. The assemblage in Zone NP16 is characterized by common to abundant $C$. pelagicus, $C$. solitus, Reticulofenestra dictyoda, Reticulofenestra onusta, and common $R$. umbilica. Between
Cores 105-647A-52R and 105-647A-51R, R. onusta is a dominant element in the assemblage, while below this level, the species is mostly rare to absent.

The interval from Sample 105-647A-57R, CC to Sample 105647A-63R-1, 36-38 cm, lies between the highest occurrence of Nannotetrina cristata and the occurrence of Chiasmolithus gigas. The range of $C$. gigas defines Subzone CP13b of Okada and Bukry (1980), which correlates with Zone NP15 of Martini and Müller (1986). Thus, this interval was assigned to Zone NP15, while Sample 105-647AS-63R-1 36-38 cm, also can be assigned to Subzone CP13b. The assemblage in Zone NP15 contains rare but definite $(>14 \mu \mathrm{m}) R$. umbilica, as well as few to common Toweius pertusus and Toweius callosus.

The intervals from Sample 105-647A-63R-2, 36-38 cm, to Sample 105-647A-65R, CC are barren of calcareous nannofossils and could not be zoned. This barren section separates nannofossil-bearing sediments of Zone NP15 (Subzone CP13b) from those of Zone NP13.

Samples 105-0647A-66R-1, 52-54 cm, and 105-647A-66R-2, 49-51 cm, contain Discoaster lodoensis, but they lie above the highest occurrence of Tribrachiatus orthostylus and do not contain Discoaster sublodoensis (Table 4). Thus, these samples were assigned to Zone NP13. Nannofossil abundance is low, and preservation is moderate to poor in these two samples. The assemblage contains common Coccolithus pelagicus and Reticulofenestra dictyoda, and few Discoaster lodoensis and Discoaster kuepperi.

Samples 105-647A-67R-1, 140-142 cm, to 105-647A-68R-4, $36-38 \mathrm{~cm}$, contain both Discoaster lodoensis and Tribrachiatus orthostylus, and thus were assigned to Zone NP12. The nannoflora is abundant and is dominated by $C$. pelagicus and Toweius occultatus. Discoaster lodoensis and D. kuepperi are few but consistently present through this zone.

Samples 105-647A-70R-1, 47-49 cm, to 105-647A-71R-2, 41 $\mathrm{cm}$, lie below the lowest occurrence of $D$. lodoensis and contain Tribrachiatus orthostylus but not $T$. contortus. Therefore, this interval was assigned to Zone NP11. The assemblage contains common to abundant $C$. pelagicus and common Toweius occultatus and Toweius magnicrassus. In addition, D. kuepperi is few to common in abundance and occurs in the lowest sample above basement, Sample 105-647A-71R-2, $41 \mathrm{~cm}$.

\section{COMMENTS ON HIGH-LATITUDE BIOSTRATIGRAPHY}

\section{Oligocene}

Several high- and low-latitude species' datums were proposed by other authors to subdivide the standard Oligocene calcareous nannofossil zones. None of these were useful at Site 647. Okada and Bukry's (1980) low-latitude zonation used the lowest occurrence of $S$. distentus to subdivide Zone NP23, and the acme of Ericsonia fenestrata $(=E$. subdisticha $)$ to subdivide the basal Oligocene Zone NP21. In Hole 647A, the lowest occurrence of $S$. distentus is below the NP22/NP23 boundary, while $E$. fenestrata is common throughout Zone NP21 and does not exhibit any clearly defined acme. Müller (1976) and Martini and Müller (1986) proposed the use of the lowest occurrence of Cyclicargolithus abisectus to approximate the lowest occurrence of $S$. ciperoensis in high latitudes, where $S$. ciperoensis is rare or absent. However, problems occur with this datum because Cyclicargolithus abisectus appears to evolve from Cyclicargolithus floridanus and is distinguished from the latter mainly by size. Wise (1983) stated that the holotype of $C$. abisectus has a diameter of $9 \mu \mathrm{m}$ and, using this lower size limit to distinguish the two species, traced $C$. abisectus down to the level of the highest occurrence of Reticulofenestra umbilica (NP22/NP23 boundary) in DSDP Hole 513A. Parker et al. (1985) also used speci- 
Table 1. Oligocene calcareous nannofossils from Hole 647A.

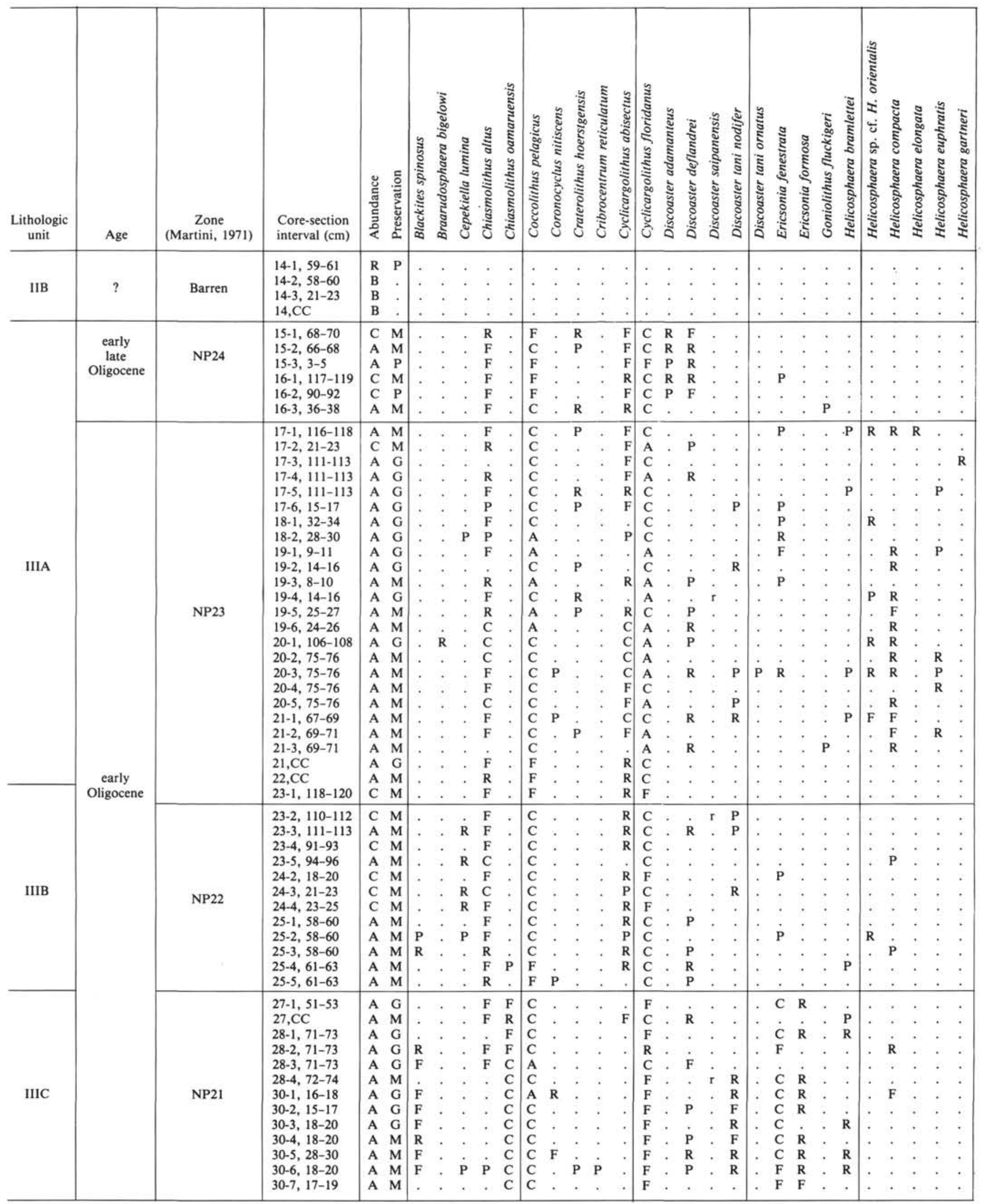

Abundances are characterized by $\mathrm{A}=$ abundant, $\mathrm{C}=$ common, $\mathrm{F}=$ few, $\mathrm{R}=$ rare, $\mathrm{P}=$ present, $\mathrm{r}=$ reworked, and $\mathrm{B}=$ barren.

Preservation is characterized by $\mathrm{G}=$ good, $\mathrm{M}=$ moderate, and $\mathrm{P}=$ poor. 


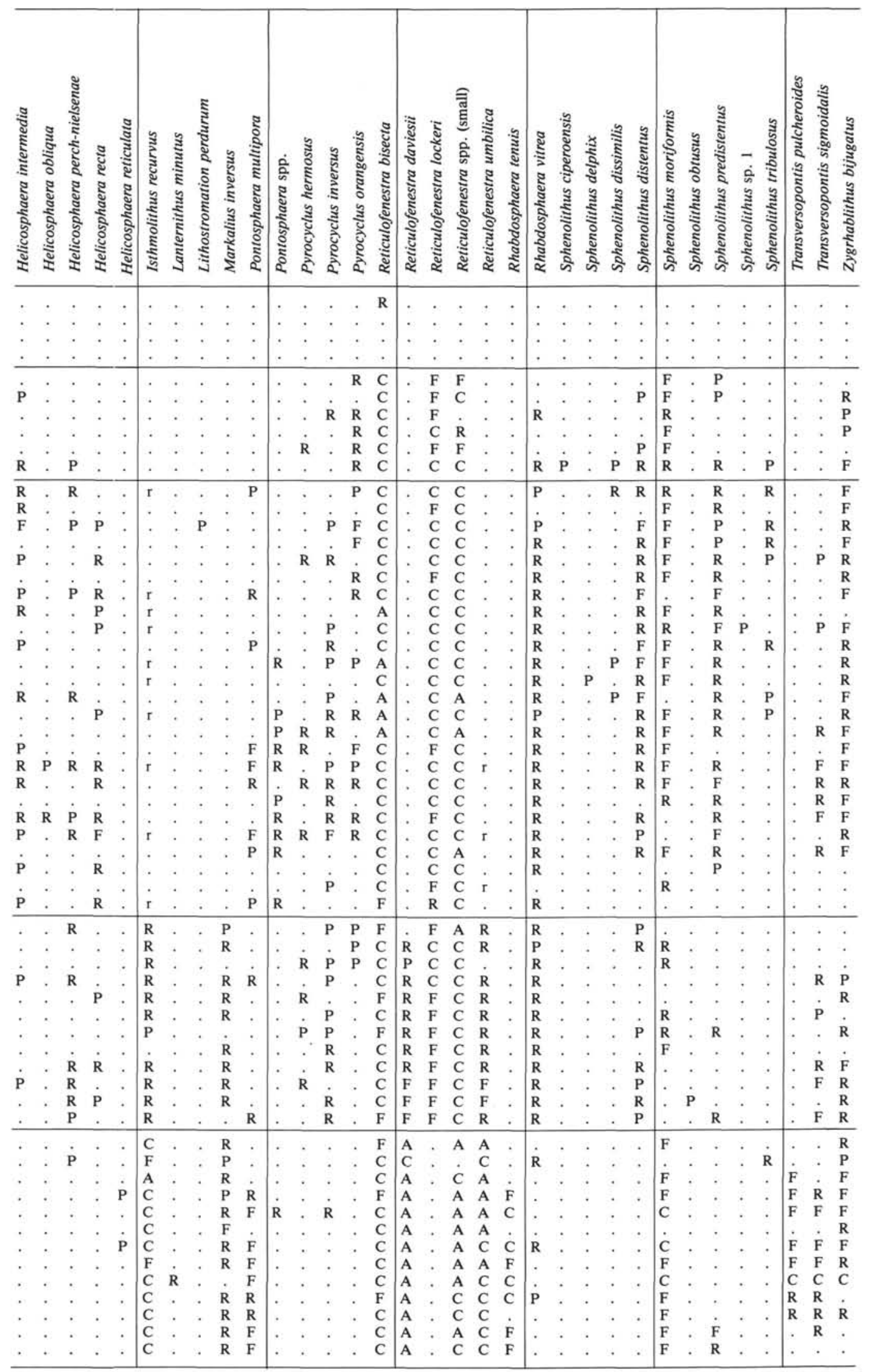


Table 2. Upper Eocene calcareous nannofossils from Hole 647A.

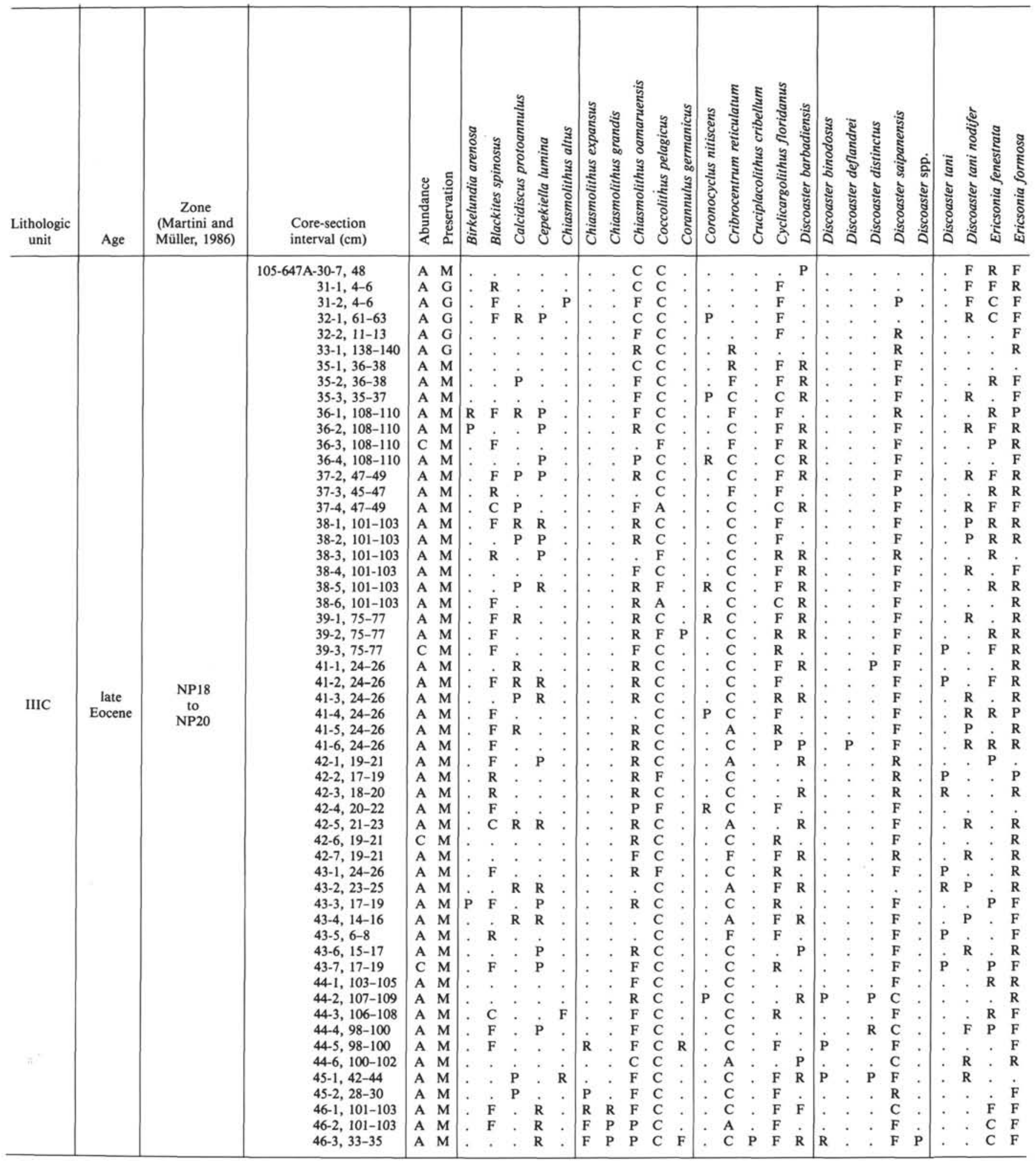

Abundances are characterized by the following: $\mathrm{A}=$ abundant, $\mathrm{C}=$ common, $\mathrm{F}=$ few, $\mathrm{R}=$ rare, $\mathrm{P}=$ present, $\mathrm{r}=$ reworked, and $\mathrm{B}=$ barren.

Preservation is characterized by $\mathrm{G}=\operatorname{good}, \mathrm{M}=$ moderate, $\mathrm{P}=$ poor. 


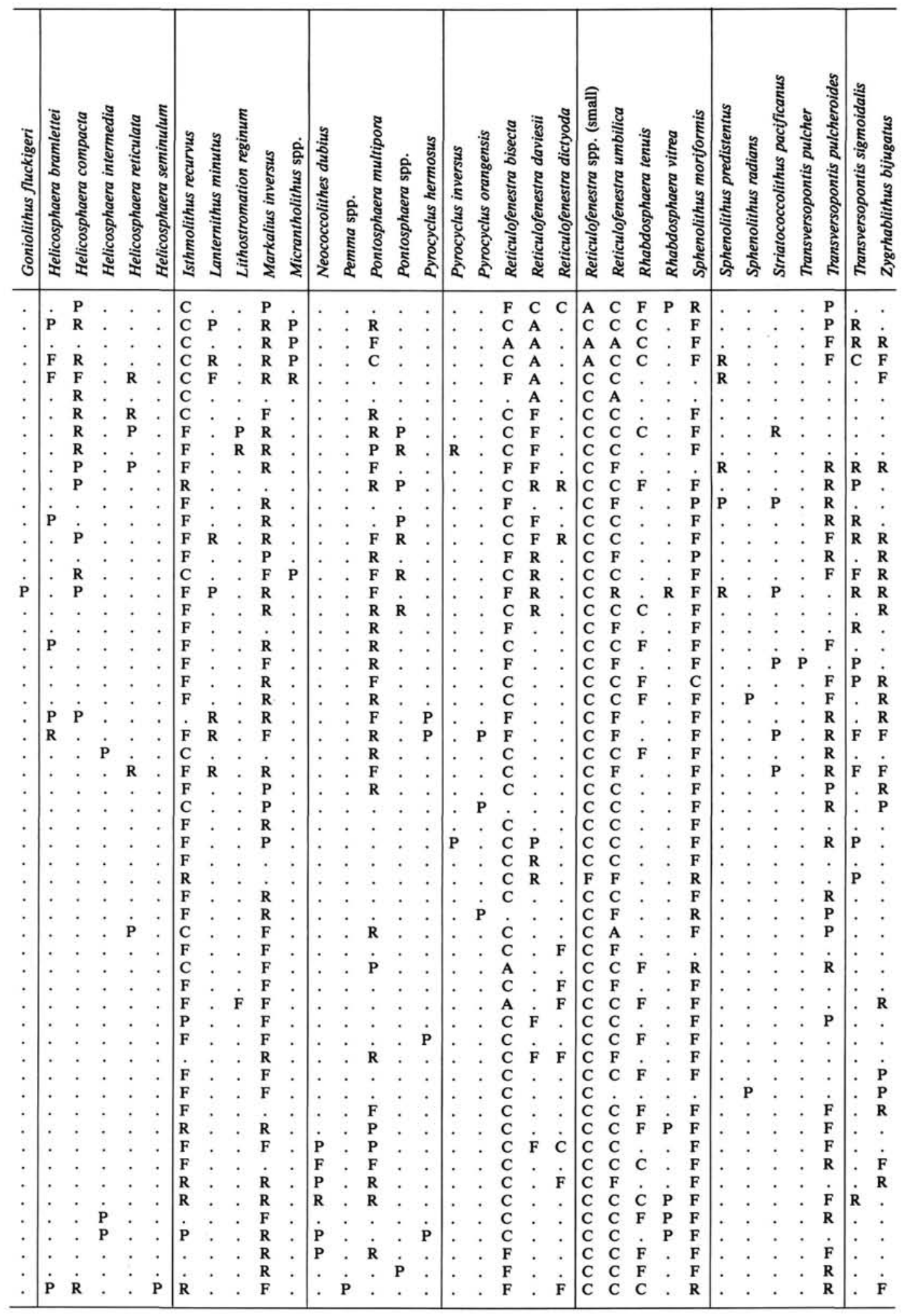


Table 3. Middle Eocene calcareous nannofossils from Hole 647A.

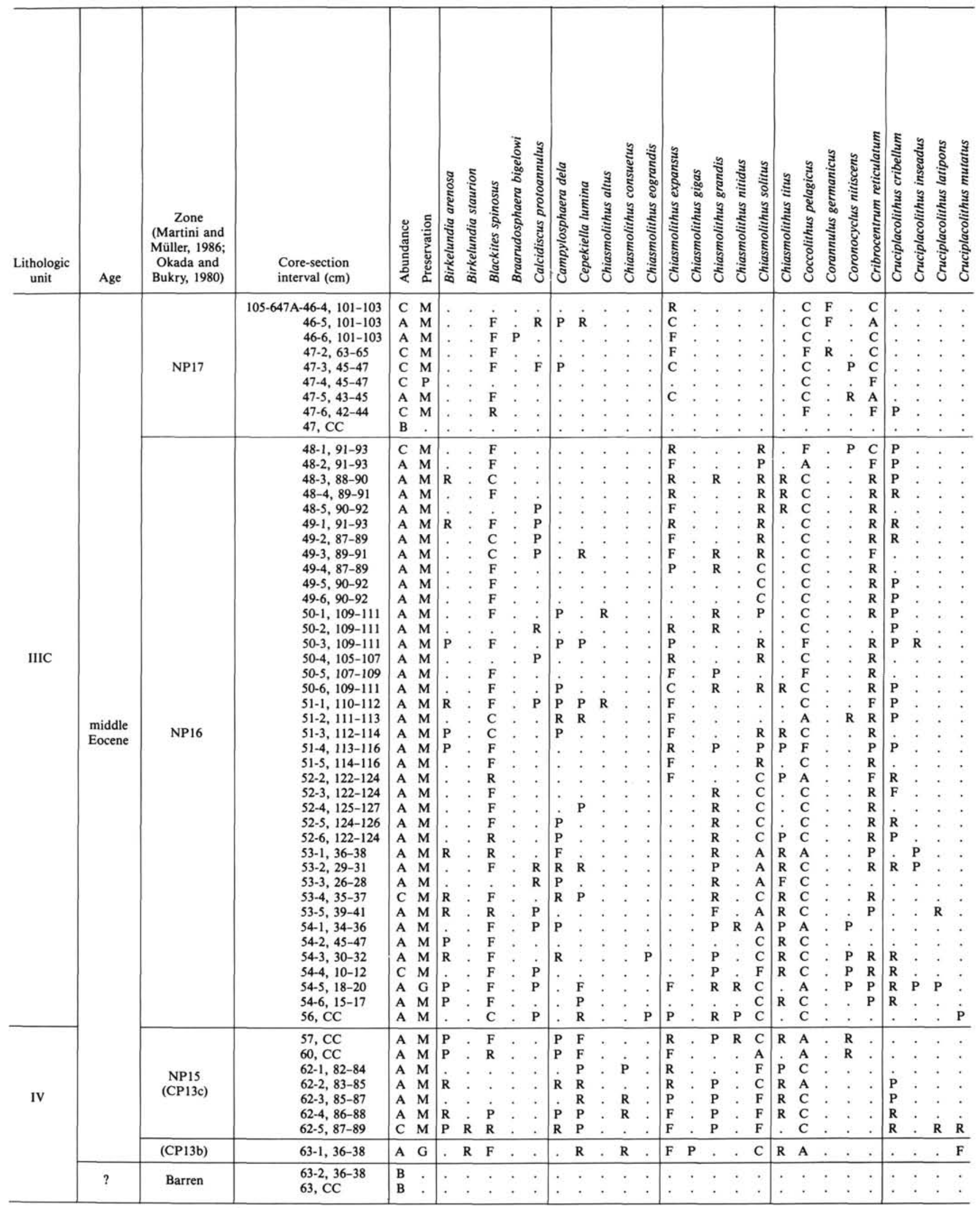

Abundances are characterized by $\mathrm{A}=$ abundant, $\mathrm{C}=$ common, $\mathrm{F}=\mathrm{few}, \mathrm{R}=$ rare, $\mathrm{r}=$ reworked, and $\mathrm{B}=$ barren.

Preservation is characterized by $\mathrm{G}=$ good, $\mathrm{M}=$ moderate, $\mathrm{P}=$ poor. 


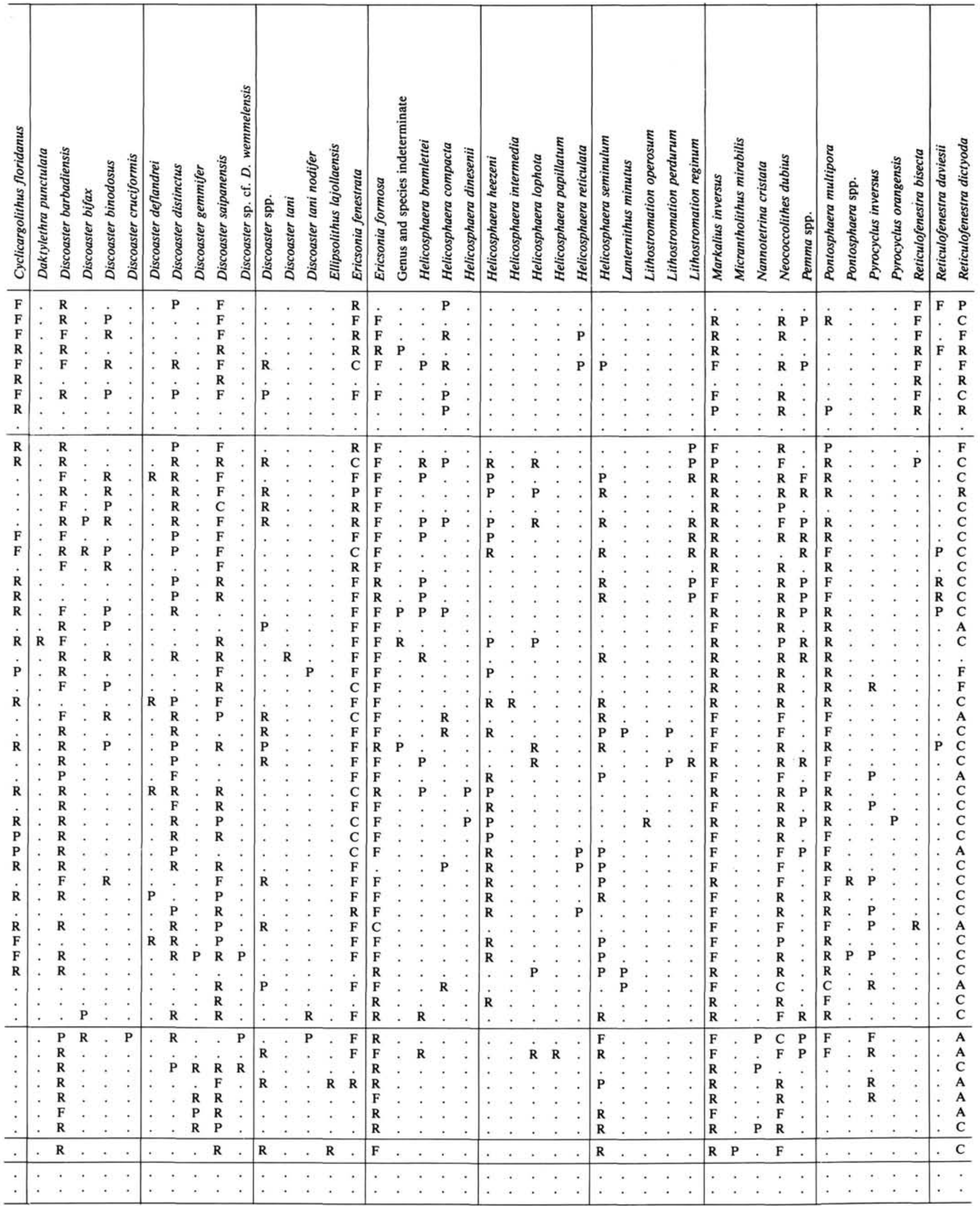


Table 3 (continued).

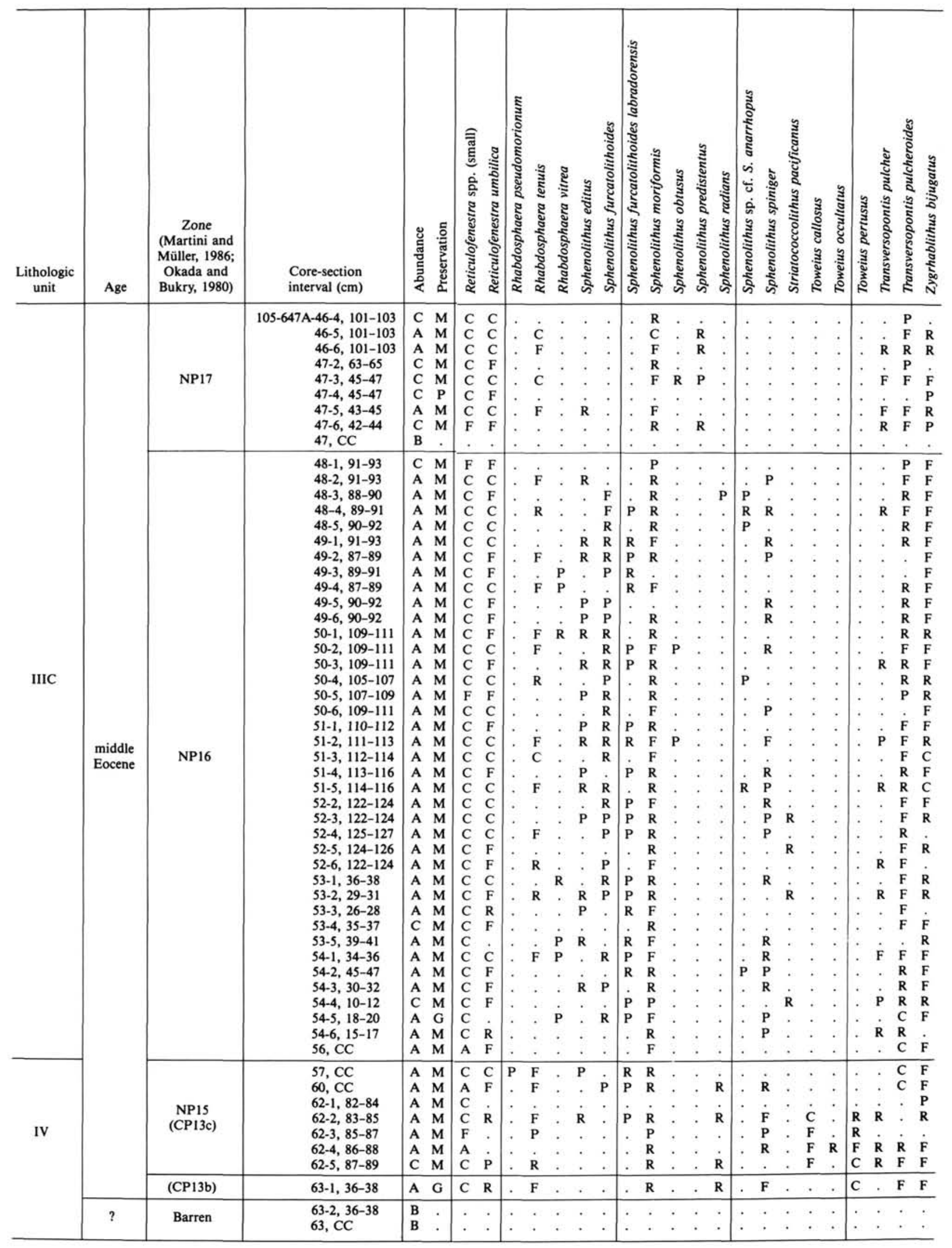


mens of $9 \mu \mathrm{m}$ or larger to define this species and traced it to the base of Zone NP22 (CP16c) at DSDP Hole 558. Similarly, Müller (1985) recorded the lowest occurrence of $C$. abisectus lower than that of $S$. ciperoensis in DSDP Holes 548A and 549A. $S$. ciperoensis in these holes is rare to few in abundance and is consistently present above its lowest occurrence. In Hole 647A, specimens of $9 \mu \mathrm{m}$ size occur as low as the upper Eocene. Therefore, a cutoff of $11 \mu \mathrm{m}$ was used, but specimens of this size or larger range down to just below the NP21/NP22 boundary. Clearly, this species is not useful for subdividing the middle Oligocene at Site 647. Thus, the middle Oligocene at high latitudes remains difficult to subdivide.

A rare species, Craterolithus hoerstgensis (Firth, in press), occurs in Zone NP23 to lower Zone NP24 at Site 647. To date, this species has been recorded from only three localities, but it has a consistently short range within the middle Oligocene. The species was originally reported by Müller (1970) to occur within the Sphenolithus distentus Zone (NP24) in Germany. However, the species list from Müller's section (Horizons $C_{2}$ and D) did not include Sphenolithus ciperoensis, the marker for NP24, although $S$. distentus was reported. It may be more accurate to assign Müller's samples to the Sphenolithus predistentus Zone (NP23). Thus, the range of $C$. hoerstgensis in Germany seems to fall in Zone NP23. When present, $C$. hoerstgensis may be of value for correlating high-latitude sections of middle Oligocene age.

\section{Eocene}

The upper Eocene of Hole 647A consists of one composite zone, NP18-NP20. Various markers used to subdivide this interval by other authors were not useful in Hole 647A. The lowest occurrence of Isthmolithus recurvus coincides with that of Chiasmolithus oamaruensis at the base of the upper Eocene, while Sphenolithus pseudoradians does not occur at this site. Okada and Theirstein (1979) also reported coincident lowest occurrences of $I$. recurvus and $C$. oamaruensis in the western North Atlantic (DSDP Site 386). In low latitudes, Levin and Joerger (1967) reported $I$. recurvus occurring low in the upper Eocene coincident with rare $C$. oamaruensis. In the high latitudes of the eastern North Atlantic, Zone NP18 is often thin but present (Müller, 1979, 1985; Takayama and Sato, 1987). The absence of Zone NP18 appears to be restricted to the western part of the North Atlantic. This can be interpreted in one of three ways: (1) as an unconformity, (2) as an anomalously high first occurrence of C. oamaruensis, or (3) as an anomalously low first occurrence of $I$. recurvus. In Hole $647 \mathrm{~A}$, no significant lithologic change was seen in the cores; no marked change was observed in the nannoflora through this interval, nor was there any indication from other microfossil groups of an unconformity (see Site 647 chapter, Srivastava, Arthur, et al., 1987); thus, the first interpretation probably can be excluded. According to Berggren et al.'s (1985) time scale, the time span represented from the lowest occurrence of I. recurvus to the top of the Eocene is about $1 \mathrm{Ma}$. If the lowest occurrence of $C$. oamaruensis is anomalously high and that of $I$. recurvus is "normal," this would necessitate that the sediment accumulation rate for this interval (Samples 105-647A-30R-7, $48 \mathrm{~cm}$, to 105-647A-46R-3, $33-35 \mathrm{~cm}$ ) be on the order of $150 \mathrm{~m} / \mathrm{m} . \mathrm{y}$. or $15 \mathrm{~cm} / \mathrm{k} . \mathrm{y}$. This rate is anomalously high for a hemipelagic environment. The third possibility, that the lowest occurrence of $I$. recurvus is anomalously low at Site 647 , appears to be the most plausible. Since $I$. recurvus is more common in high-latitude regions, the species may have originated in the high latitudes and subsequently migrated to lower latitudes. Its lowest occurrence datum then would be diachronous and appear lower in the high latitudes than in the low latitudes. Such a scenario may explain the range of occurrence of $I$. recurvus in Hole 647A.
The highest occurrence of Chiasmolithus solitus was found to be diachronous and thus not useful in a number of DSDP sections (Beckmann et al., 1981). Bukry (1973) proposed using the last occurrence of Discoaster bifax as an alternative marker for the highest occurrence of $C$. solitus to subdivide the interval between the lowest occurrence of $R$. umbilica and the lowest occurrence of $C$. oamaruensis. Beckmann et al. (1981) also found that $D$. bifax was not useful because of its scarcity in several DSDP sections. In Hole 647A, D. bifax is rare and scattered and could not be used reliably to delineate the CP14a/CP14b boundary.

Bukry (1973) stated that Reticulofenestra bisecta becomes established in the Discoaster saipanensis Subzone (= NP17) of the Reticulofenestra umbilica Zone. In Hole 647A, the lowest occurrence of Reticulofenestra bisecta is slightly lower (Sample $105-647 \mathrm{~A}-48 \mathrm{R}-3,88-90 \mathrm{~cm}$ ) than the highest occurrence of $C$. solitus (Sample 105-647A-48R-1, 91-93 cm). This datum coincides with the highest occurrence of $C$. solitus in DSDP Site 386 (Okada and Theirstein, 1979), Hole 548A (Müller, 1985), and Hole 400A (Müller, 1979). In addition, the lowest occurrence of $R$. bisecta falls within the $R$. umbilica Zone (NP16-NP17) in DSDP Holes 362A and 363 (Proto-Decima et al., 1978) and in Hole 360 (MacKenzie and Wise, 1983), and it occurs in two samples (about $2 \mathrm{~m}$ ) below the highest occurrence of $C$. solitus in Site 538A (Lang and Watkins, 1984). In Islas Orcados (IO) Core $16-43, R$. bisecta co-occurs with $C$. solitus over an interval of $60 \mathrm{~cm}$, but in IO Core 16-44, no $R$. bisecta was reported in conjunction with $C$. solitus in the Discoaster bifax Subzone (Wise and Mostajo, 1983). However, IO Core 16-44 may be a sample from a stratigraphically lower level than IO Core 16-43 (Wise and Mostajo, 1983). Bybell (1975) reported the co-occurrence of these two species over a large interval (about $50 \mathrm{~m}$ ) within the middle Eocene Claiborne group of Alabama. Despite this last discrepancy, the two occurrences in deep-sea cores are very close and have only a small amount of overlap at some sites. The lowest occurrence of $R$. bisecta in the deep sea seems stratigraphically consistent over a wide geographic range and may prove useful for subdividing the $R$. umbilica Zone (NP16NP17) when the highest occurrence of $C$. solitus cannot be used.

In the lower Eocene, Imperiaster obscurus and Micrantholithus mirabilis have consistent stratigraphic ranges within a short interval (NP11 to NP13) in high-latitude, shallow-water areas (Bukry, 1972; Martini, 1958; Muller, 1976, 1979; PerchNielsen, 1968, 1972). Their presence in Hole 647A is consistent with their high-latitude occurrences in the eastern North Atlantic, although they have not been recorded previously from the Labrador Sea. Although benthic foraminifers in the lower Eocene of Site 647A indicate a lower bathyal paleodepth of 1000$2000 \mathrm{~m}$ (Kaminsky et al., this volume), the rare occurrence of $I$. obscurus and $M$. mirabilis in this interval does not negate the interpretation of these species being more common in shallowwater areas (Müller, 1979). In high-latitude, nearshore areas, these species may be useful for correlating sediments of Zones NP11 to NP13 age when primary markers are not present.

\section{REEXAMINATION OF DSDP SITE 112}

The study of calcareous nannofossil assemblages from the continuously cored Paleogene section at Site 647 provided a basis for correlation with the Paleogene assemblages from nearby DSDP Site 112 (Fig. 2). A range chart and zonation for the Oligocene and Eocene of DSDP Site 112 are given in Table 5. Perch-Nielsen (1972) and Bukry (1972) issued initial reports about the calcareous nannofossil biostratigraphy of this site, while Aubry (in Miller et al., 1982) reevaluated the zonal assignments for the Eocene to lower Oligocene part of the hole. I found several discrepancies in zonal assignments between my results and those of Bukry (1972) and Perch-Nielsen (1972). 
Table 4. Lower Eocene calcareous nannofossils from Hole 647A.

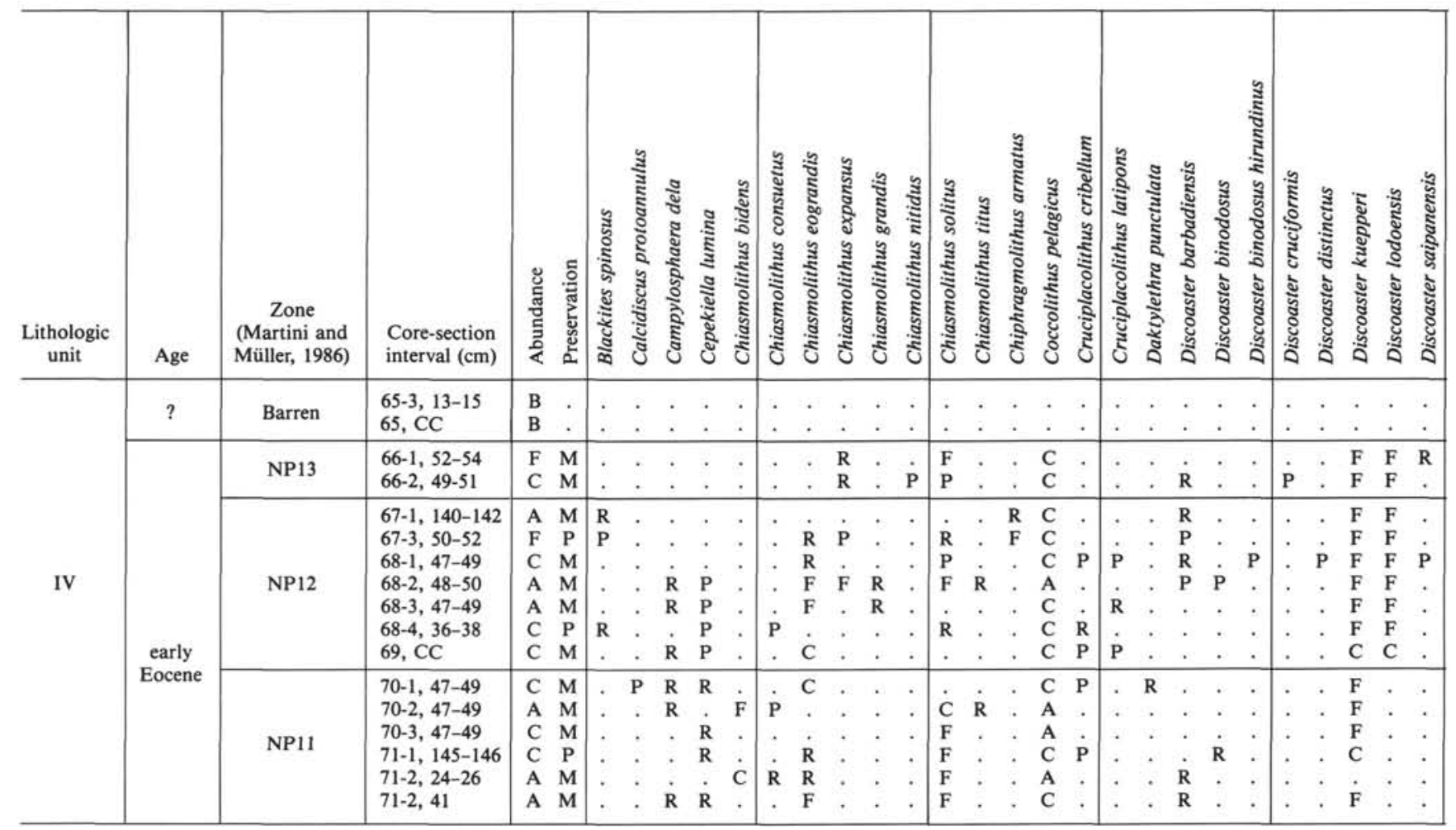

Abundances are characterized by $\mathbf{A}=$ abundant, $\mathrm{C}=$ common, $\mathrm{F}=$ few, $\mathrm{R}=$ rare, $\mathrm{r}=$ reworked, and $\mathrm{B}=$ barren.

Preservation is characterized by $\mathrm{G}=\operatorname{good}, \mathrm{M}=$ moderate, and $\mathrm{P}=$ poor.

Samples $12-112-5-1,85-89 \mathrm{~cm}$, to $12-112-11-4,69-73 \mathrm{~cm}$, were assigned to Zone NP23 (Sphenolithus predistentus Zone), based on the absence of Reticulofenestra umbilica and Sphenolithus ciperoensis and the presence of characteristic Oligocene species, such as Chiasmolithus altus, Cyclicargolithus floridanus, Cyclicargolithus abisectus, and Reticulofenestra bisecta. The presence of $C$. abisectus in this interval does not necessarily indicate a zonal assignment equivalent to the $S$. distentus Zone (NP24), as suggested by Müller (1976). In nearby Hole 647A, $C$. abisectus $(>11 \mu \mathrm{m})$ occurs down to the base of Zone NP22. Additional evidence for assigning these samples to Zones NP23 to lower NP24 is the presence in the upper part of this interval of Craterolithus hoerstgensis. This species has been reported elsewhere only in Zones NP23 to lower NP24 at Site 647 and in Zone NP23 from Germany (Müller, 1970). Correlations based on diatoms (Baldauf and Monjanel, this volume) and benthic foraminifers (Kaminski et al., this volume) agree with the nannofossil assignment of Zone NP23.

Sample 12-112-12-1, 44-48 cm, contains Reticulofenestra umbilica, but does not contain Ericsonia formosa and thus was assigned to Zone NP22. This assignment contrasts with those of Perch-Nielsen (1972) and Bukry (1972), who assigned Core 12112-12 to the lowermost Oligocene zone, equivalent to Zone NP21 of Martini (1971). Neither author reported the presence of E. formosa in Core 12-112-12, which would corroborate such an age assignment. Aubry (in Miller et al., 1982) also assigned Core 12-112-12 to Zone NP22. Benthic foraminifer correlations (Kaminski et al., this volume) equate this level with the unsampled interval between Cores 105-647A-25R and 105-647A-27R, which corresponds roughly to the NP21/NP22 boundary.

Core 12-112-13 lies within the upper Eocene (NP18-NP20) and contains Discoaster barbadiensis, Discoaster saipanensis, Chiasmolithus oamaruensis, Isthmolithus recurvus, Reticulofe- nestra bisecta, and Cribrocentrum reticulatum. This Zonal assignment is broader than that of Aubry (in Miller et al., 1982), who assigned this core to Zone NP19. At nearby Site 647, the upper Eocene is undifferentiated because the lowest occurrence of $I$. recurvus is anomalously low and coincides with the occurrence of $C$. oamaruensis. In addition, I did not observe Sphenolithus pseudoradians at Site 647. Because of the more complete recovery at Site 647 , these biostratigraphic features are more readily apparent than at Site 112 . Based on the comparison with Site 647 , I prefer a broader zonal assignment for Core 12-11213. Kaminski et al. (this volume) used benthic foraminifer data to correlate Core $12-112-13$ to the interval from Cores 105$647 \mathrm{~A}-36 \mathrm{R}$ to $105-647 \mathrm{~A}-40 \mathrm{R}$, or the middle of Zones NP18NP20.

Core 12-112-14 was recovered below the lowest occurrence of Chiasmolithus oamaruensis and thus is of middle Eocene age. Chiasmolithus solitus is absent in this core, which suggests that it lies above the highest occurrence of that species (NP16/NP17 boundary). This interpretation is supported by the presence of Reticulofenestra bisecta throughout this core. $R$. bisecta first occurs just below the NP16/NP17 boundary in nearby Hole $647 \mathrm{~A}$. The presence of this species, coupled with the absence of C. oamaruensis, is useful for recognizing Zone NP17.

Sample 12-112-15-6, 110-114 cm, contains Discoaster sublodoensis and Rhabdosphaera inflata and was assigned to Zone NP14 (Subzone CP12b of Okada and Bukry, 1980). Sample 12$112-15-1,6-10 \mathrm{~cm}$, contains a similar assemblage to Sample 12$112-15-6,110-114 \mathrm{~cm}$, but does not contain $R$. inflata. Bukry (1972) listed the presence of $R$. inflata slightly lower, in Sample $12-112-15-1,47-48 \mathrm{~cm}$. This indicates that Sample 12-112-15-1, $6-10 \mathrm{~cm}$, lies above the highest occurrence of $R$. inflata and that it can be assigned to Subzone CP13a of Okada and Bukry (1980). No specimens of Nannotetrina were found in Sample 


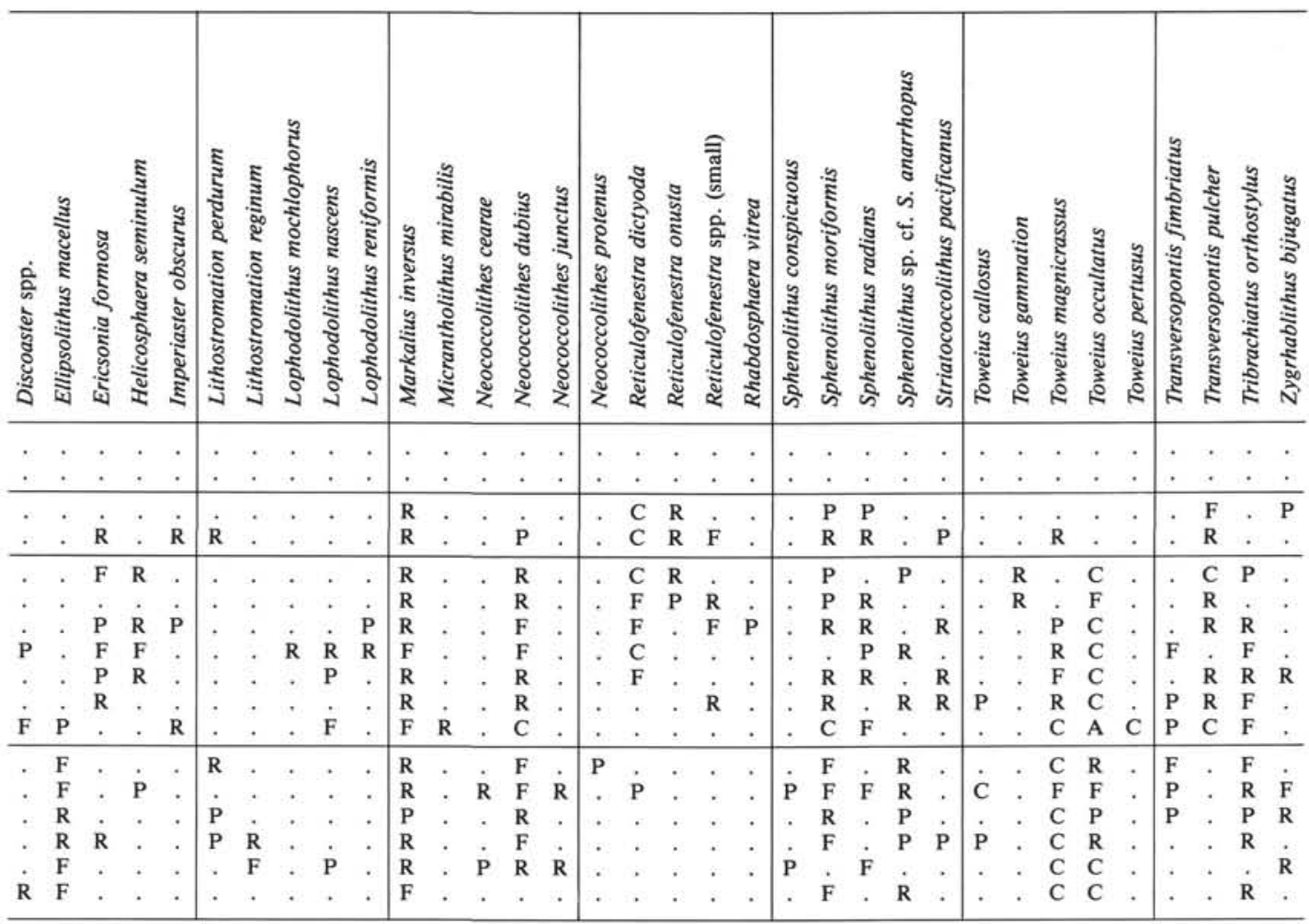

$12-112-15-1,6-10 \mathrm{~cm}$, although this may be the result of environmental exclusion from this high-latitude site (Nannotetrina is very rare at Site 647). Therefore, Sample 12-112-15-1, 6-10 $\mathrm{cm}$, also was assigned tentatively to Zone NP14. Kaminsky et al. (this volume) assign Cores 12-112-14 and 12-112-15 to the Nuttallides trumpyi benthic foraminifer assemblage, which correlates with Zones NP15 to NP17 in Hole 647A. Sample 12-112$16-1,85-89 \mathrm{~cm}$, was barren of nannofossils.

\section{PALEOECOLOGY}

The Paleogene sequence at Site 647 is characterized by very high species abundance, compared with other Eocene-Oligocene sequences in the North Atlantic (Bukry, 1972; Okada and Theirstein, 1979; Müller, 1976, 1979, 1985; Parker et al., 1985; Perch-Nielsen, 1972;). This may be because of more detailed sampling in the thicker sequence at Site 647, which allowed more opportunities to observe rare species. However, the possibility exists that at Site 647 calcareous nannofossil species abundance is actually higher than in other regions.

Haq et al. (1977) delineated five major Oligocene nannofossil assemblages in the Atlantic Ocean. The lower to lower upper Oligocene nannoflora at Site 647 (NP22-NP24) is a mix of their high-latitude reticulofenestrid-- $R$. bisecta assemblage and their middle-latitude Cyclicargolithus floridanus assemblage. The latter assemblage was more pronounced in the lower latitudes during the early Oligocene (Haq et al., 1977). In addition, numerous species of Helicosphaera, Discoaster, and Sphenolithus occur, although relative abundances of individual species are low. A highly diverse assemblage, such as was found at Site 647 , suggests the influence of more temperate surface waters in this region through the lower to lower upper Oligocene. The lowest Oligocene (NP21) assemblage at Site 647 consists of the highlatitude reticulofenestrid- $R$. bisecta assemblage, with an abundance of the cold-water species Isthmolithus recurvus.
The upper Eocene nannoflora is a mix of Haq et al.'s (1977) middle-latitude Reticulofenestra umbilica and Cribrocentrum reticulatum assemblages. The sample most closely approximating the $R$. umbilica assemblage, according to Haq et al. (1977), is Sample 12-112-13-14 from the upper Eocene of nearby Site 112. Species abundance is low when compared to the middle Eocene and is only slightly greater than in the lower Oligocene. The decline in nannofossil species abundance across the Eocene/Oligocene boundary in Hole $647 \mathrm{~A}$ is less than that which occurs from the middle Eocene to upper Eocene (Fig. 3).

The middle Eocene nannoflora has a high species abundance, including many species more typical of lower latitudes, and/or nearshore shelf environments. However, the middle- and high-latitude elements, such as Reticulofenestra, Chiasmolithus, and Coccolithus, remain dominant. Species that are more common in nearshore, shallower water environments, such as holococcoliths and species of Transversopontis, Pontosphaera, Helicosphaera, and Pemma, are diverse, yet do not attain high abundances within this interval. This indicates a relatively deep water paleoenvironment for the site. The lowest samples containing middle Eocene nannofossils, in Zone NP15, contain common Toweius pertusus and Coccolithus pelagicus and may represent the last occurrence in this region of the Toweius pertusus $(=T$. craticulus of Haq et al., 1977) assemblage defined by Haq et al. (1977). This assemblage occurred first in the lower latitudes in the Paleocene and gradually expanded to more northerly latitudes in the early to early middle Eocene. Thus, the nannoflora indicates that warmer temperatures in the early middle Eocene gave way to more temperate conditions through the rest of the middle Eocene.

Species indicative of neritic environments, such as Transversopontis pulcher and $T$. fimbriatus, are more common in the lower Eocene. In addition, the presence of Imperiaster obscurus and Micrantholithus mirabilis in a few samples suggests that the 


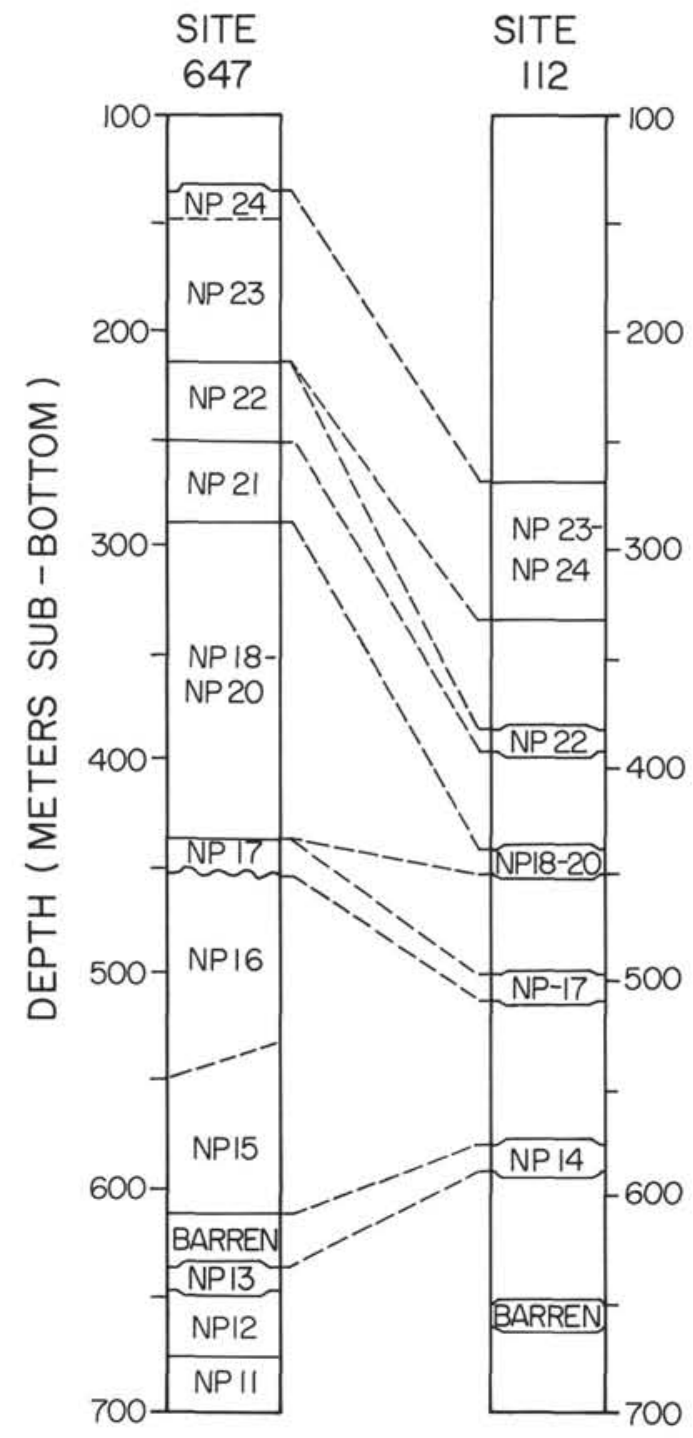

Figure 2. Correlation of Eocene-Oligocene sediments in Holes 647A and 112 .

early Eocene in closer proximity to shelf regions and/or more reworking of shelf (neritic) elements than in later time (Müller, 1979). The lower Eocene nannoflora at Site 647 is diverse and contains common $C$. pelagicus, Toweius magnicrassus, $T$. occultatus, and few to common Discoaster kuepperi and D. lodoensis. Such an assemblage is characteristic of warmer waters (Haq et al., 1977). This agrees with the results of Gradstein and Srivastava (1980), who concluded that incursions of warm-temperate surface waters took place in the Labrador Sea during early to middle Eocene time, based on planktonic foraminifer data.

\section{SUMMARY}

At Site 647 in the southern Labrador Sea, a nearly complete sequence of lower upper Oligocene to lower Eocene sediments was recovered that contains a very diverse high-latitude nannoflora. A summary of the calcareous nannofossil biostratigraphy and paleoceanography of the site follows.

The oldest sediments recovered directly above basement are of early Eocene age (Zone NP11). The lower Eocene nannoflora is indicative of warm-temperate surface waters and includes elements suggestive of nearby neritic environments. Deposition of nannofossiliferous sediments at Site 647 continued through Zone NP13 time. An interval barren of nannofossils separates the lower Eocene from lower middle Eocene sediments (Zone NP15, Subzone CP13b).

The lower middle Eocene nannoflora contains vestiges of a warm-water assemblage that extended poleward in early middle Eocene time before dissappearing (Haq et al., 1977). The rest of the middle Eocene contains a diverse middle-latitude assemblage, which indicates a cooling of water conditions from the early Eocene. Subdivision of the middle Eocene was difficult because of rare marker species. However, sedimentation appears continuous throughout the middle Eocene, except for a possible short hiatus or period of reduced sedimentation rate separating Zones NP16 and NP17 in the upper middle Eocene.

The upper Eocene at Site 647 was not differentiated because of the lack of useful marker species in this interval. The nannoflora suggests middle-latitude, temperate conditions, in continuance with the cooling trend seen in the middle Eocene. The Eocene/Oligocene boundary appears to be complete, and no major extinctions or changes in the nannoflora were observed across the boundary interval.

The lower Oligocene (NP21) is characterized by a typical highlatitude, colder water assemblage. At the base of Zone NP22, lithology changes from nannofossil claystones below to biogenic silica-rich claystones above. Concurrent with this change is a change in the nannoflora to a mixed assemblage of high- and middle-latitude species. This assemblage extends through the lower and lower upper Oligocene. The upper Oligocene is about $15 \mathrm{~m}$ thick and is truncated by an unconformity that separates it from the overlying Neogene sequence.

Comparison with nannofossil assemblages from nearby DSDP Site 112 resulted in the reassignment of Cores $12-112-5$ to 12 112-11 from the upper to the lower Oligocene and a broader upper Eocene age assignment for Core 12-112-13.

\section{SYSTEMATIC PALEONTOLOGY}

Genus CRUCIPLACOLITHUS Hay and Mohler in Hay et al. (1967) Cruciplacolithus inseadus Perch-Nielsen, 1969

(Pl. 1, Figs. 12 and 13)

Remarks. Cruciplacolithus inseadus is a small but distinctive species described from the Danian of Denmark. It differs from other species of Cruciplacolithus by having four diagonal crossbars attached to the two main crossbars, which form a diamond-shaped central structure. Very rare specimens containing this distinctive central structure were found in samples within Zone NP16 at Site 647. The specimens are small $(<5$ $\mu \mathrm{m})$ and have a dark outer shield under cross-polarized light. The inner cycle of elements around the central hole birefringes under cross-polarized light, as do the crossbars. However, because they are so small and thin, these crossbars are not very bright and consequently are hard to see.

Occurrence. The previously reported range of this species is within the lower Paleocene (Perch-Nielsen, 1985). These specimens possibly may be reworked, although no other species characteristic of the lower Paleocene were observed from Site 647 samples. Because of its small size and rare occurrence, this species may have been overlooked in Eocene sediments elsewhere.

\section{Genus DISCOASTER Tan, 1927}

Remarks. Several rare and poorly preserved discoaster species, other than those species recorded in the range charts, were encountered at Site 647. Their combined occurrences and abundances are listed in Tables 2-4 under Discoaster spp.

Genus and Species Indeterminate

$$
\text { (Pl. 2, Figs. 1-5) }
$$

Remarks. This nannofossil resembles a hat in that it contains a narrow brim and a rounded, dome-like top. The brim consists of two shields, slightly separated. The base of the dome displays a ring of small 
holes. The domelike top is covered with perforations smaller than the basal holes. The generic affiliation of this form is uncertain.

Occurrence. This form occurs very rarely within Zones NP16-NPI7 at Site 647, Labrador Sea.

Size. Height $=5.6 \mu \mathrm{m}$; width $=8.8 \mu \mathrm{m}$.

\section{Genus PEMMA Klump, 1953}

Remarks. Rare fragments of specimens of Pemma were encountered through the Eocene. I did not attempt to differentiate this genus into species.

\section{Genus PONTOSPHAERA Lohmann, 1902}

Remarks. A number of different species of Pontosphaera (other than Pontosphaera multipora) are present at Site 647, but they are represented by only rare specimens and thus were combined into Pontosphaera spp.

Genus RETICULOFENESTRA Hay, Mohler, and Wade, 1966

Remarks. Wise's reasoning (1983) for considering Dictyococcites as a junior synonym of Reticulofenestra was followed here. Specimens of Reticulofenestra that are $5 \mu \mathrm{m}$ in size or less were combined under Reticulofenestra spp. (small) for this report.

\section{Reticulofenestra bisecta (Hay, Mohler, and Wade) Roth, 1970} (Pl. 4, Figs. 2-4)

Syracosphaera bisecta Hay, Mohler, and Wade, 1966, p. 393, Pl. 10, Figs. 4-6.

Reticulofenestra bisecta (Hay, Mohler, and Wade) Roth, 1970, p. 847, Pl. 3, Fig. 6.

Remarks. A wide range in variability was observed within this species, which encompasses the two subspecies $R$. bisecta bisecta and $R$. bisecta filewiczii. The latter form, which has a partially closed central area, is common in Hole 647A. This supports Wise's conclusion (1983) that $R$. bisecta filewiczii may be a high-latitude variant of this species.

\section{Reticulofenestra onusta (Perch-Nielsen) Wise, 1983}

$$
\text { (Pl. 2, Fig. 9) }
$$

Dictyococcites onustus Perch-Nielsen, 1971, p. 29, Pl. 20, Figs. 3-4; Pl. 61 , Figs. 28 and 29.

Reticulofenestra onusta (Perch-Nielsen) Wise, 1983, p. 505, Pl. 5, Figs. 8-9.

Remarks. Large (mean length $=13.1 \mu \mathrm{m}, \mathrm{N}=15$ ) specimens of this species occur in Samples 105-647A-66R-1, 52-54 cm, to 105-647A-67R$3,50-52 \mathrm{~cm}$, in the lower Eocene (NP12 to NP13) of Site 647 . This lower Eocene occurrence may be the lowest reported occurrence of this species. The species ranges into the upper middle Eocene (NP17), where its mean size varies greatly from sample to sample. Backman and Hermelin (1986) noted an illustration by Perch-Nielsen (1972, PI. 9, Fig. 6) of a large Reticulofenestra species from the lower Eocene (NP13) of DSDP Site 111 in the southern Labrador Sea. They measured 50 specimens of this form from the same sample (111A-8-1) and derived a mean length of $13.8 \mu \mathrm{m}$. They concluded that these large morphovariants were an undescribed species. However, the picture illustrated in PerchNielsen (1972) shows the typical large central opening with thick perforated grill indicative of $R$. onusta.

Reticulofenestra umbilica (Levin) Martini and Ritzkowski, 1968

Coccolithus umbilicus Levin, 1965, p. 265, Pl. 41, Fig. 2.

Reticulofenestra umbilica (Levin) Martini and Ritzkowski, 1968, p. 245, Pl. 1, Figs. 11 and 12.

Reticulofenestra hillae Bukry and Percival, 1971, p. 136, Pl. 6, Figs. 13.

Remarks. Backman and Hermelin (1986) analyzed a population of $R$. umbilica/R. hillae morphometrically and were unable to distinguish these two morphovariants. At Site 647, this group also displayed a wide range of variation with no distinct break in forms. Therefore, the entire population was included within the species Reticulofenestra umbilica. A lower size limit of $14 \mu \mathrm{m}$, as determined by Backman and Hermelin (1986), was used to distinguish $R$. umbilica from the smaller species $R$. dictyoda.
Genus SPHENOLITHUS Deflandre in Grasse, 1952

Sphenolithus sp. cf. S. anarrhopus

(Pl. 2, Figs. 11 and 12)

Remarks. Specimens of the genus Sphenolithus that exhibit an asymmetrical apical segment similar to $S$. anarrhopus were observed in upper middle Eocene samples (NP16) from Site 647. The apical segment becomes extinct parallel to nicols, but shows a "bent" appearance when at a slightly oblique angle to nicols ( $\mathrm{Pl}$. 2, Fig. 11). These specimens occur well above the usual reported range for $S$. anarrhopus (Paleocene to lower Eocene, Perch-Nielsen, 1985).

Sphenolithus furcatolithoides Locker, 1967 Sphenolithus furcatolithoides labradorensis n. subsp. (Pl. 2, Figs. 15 and 16; Pl. 3, Figs. 1-4)

Description. A sphenolith having a narrow proximal shield and a long, narrow, tapering apical segment. The apical segment may have straight sides or be slightly bulbous near its proximal end. The apical segment bifurcates at the apex, but this bifurcation is often broken off. Under cross-polarized light, parallel to the nicols, the apical segment is split into two parts by an extinction line. The proximal shield also is split into two parts, and it is separated from the apical segment by an extinction line that is at $90^{\circ}$ to the long axis of the specimen. At $45^{\circ}$ to the nicols, the apical segment becomes extinct, while the proximal shield is split into three parts. The central partition is thinner than the outer two and tapers apically to a point.

Remarks. This subspecies has a similar range and extinction pattern under cross-polarized light as typical forms of Sphenolithus furcatolithoides. However, the latter differs by possessing an apical segment that separates into two wide furcations near the base. Each of these furcations tapers quickly to a thin spine. In $S$. furcatolithoides labradorensis, the two halves of the apical segment remain together as they taper to a point and then bifurcate into two thin spines at the apex. No intermediate forms were observed. Sphenolithus obtusus differs from $S$. furcatolithoides labradorensis in that the apical segment birefringes at $45^{\circ}$ to nicols, rather than going extinct.

Occurrence. Middle Eocene (NP15-NP16) at Site 647, Labrador Sea; middle Eocene (NP16) at Site 356, South Atlantic (Perch-Nielsen, 1977, Pl. 49, Figs. 33 and 42-44).

Size. Holotype-length $=7.2 \mu \mathrm{m}$; Paratypes - length $=7-8 \mu \mathrm{m}$.

Holotype. Pl. 2, Figs 15 and 16.

Paratype. Pl. 3, Figs. 1-4.

Type locality. Labrador Sea, Sample 105-647A-52R-2, 122-124 cm.

Sphenolithus sp. 1

(Pl. 4, Figs. 9 and 10)

Remarks. This species consists of a round basal cycle that resembles an apical view of $S$. moriformis under cross-polarized light. Emanating from one quarter of this base is a thin spine, which tapers quickly to a point at the end of which is a small bifurcation. This spine birefringes at $45^{\circ}$ to nicols and goes extinct parallel to the nicols.

Occurrence. Only one specimen of this species was found, in Sample 105-647A-19R-1, 9-11 cm, in the lower Oligocene (NP23) at Site 647.

Size. Length $=7.2 \mu \mathrm{m}$.

\section{ACKNOWLEDGMENTS}

Support for this study was funded partially by a research grant from the Texas A\&M Research Foundation and by an equipment grant from the Amoco Foundation. Critical reviews by M.-P. Aubry, L. M. Bybell, and S. P. Srivastava are gratefully acknowledged. The author benefitted considerably from discussions with S. W. Wise, Jr., and J. A. Bergen. Rosemarie Raymond drafted the figures.

\section{REFERENCES}

Applegate, J. L., and Bergen, J. A., 1988. Lower Cretaceous calcareous nannofossil biostratigraphy of sediments recovered from ODP Leg 103, Galicia Bank. In Boillot, G., Winterer, E. L., et al., 1988. Proc. ODP, Sci. Results, 103: College Station, TX (Ocean Drilling Program).

Backman, J., and Hermelin, J.O.R., 1986. Morphometry of the Eocene nannofossil Reticulofenestra umbilica lineage and its biochronological consequences. Paleogeogr., Paleoclimatol., Paleoecol., 57:103116. 
Beckmann, J. P., Bolli, H. M., Perch-Nielsen, K., Proto-Decima, F., Saunders, J. B., and Toumarkine, M., 1981. Major calcareous nannofossil and foraminiferal events between the middle Eocene and early Miocene. Palaeogeogr., Palaeoclimatol., Palaeoecol., 36:155190.

Berggren, W. A., Kent, D. V., and Flynn, J. J., 1985. Paleogene geochronology and chronostratigraphy. In Snelling, N. J., Geochronology and the Geologic Time Scale. Geol. Soc. London, Spec. Pap.

Bukry, D., 1972. Further comments on coccolith stratigraphy, Leg 12, Deep Sea Drilling Project. In Laughton, A. S., Berggren, V. A., et al., Init. Repts. DSDP, 12: Washington (U.S. Govt. Printing Office), 1071-1083.

1973. Low-latitude coccolith biostratigraphic zonation. In Edgar, N. T., Saunders, J. B., et al., Init. Repts. DSDP, 15: Washington (U.S. Govt. Printing Office), 685-703.

Bybell, L. M., 1975. Middle Eocene calcareous nannofossils at Little Stave Creek, Alabama. Tulane Studies in Geol. Paleontol., 11(4): 177-252.

Firth, J. V., in press. Craterolithus: a new calcareous nannofossil genus from the Oligocene of the Labrador Sea. J. Paleontol.

Gradstein, F. M, and Srivastava, S. P., 1980. Aspects of Cenozoic stratigraphy and paleoceanography of the Labrador Sea and Baffin Bay. Palaeogeogr., Palaeoclimatol., Palaeoecol., 30:261-295.

Haq, B. U., Premoli-Silva, I., Lohmann G. P., 1977. Calcareous nannoplankton paleobiogeographic evidence for major climatic fluctuations in the early Cenozoic Atlantic Ocean. J. Geophys. Res., 82(27):38613876.

Lang, T. H., and Watkins, D. K., 1984. Cenozoic calcareous nannofossils from Deep Sea Drilling Project Leg 77: biostratigraphy and delineation of hiatuses. In Buffler, R. T., Schlager, W., et al., Init. Repts. DSDP, 77: Washington (U.S. Govt. Printing Office), 629648.

Levin, H. L., and Joerger, A. P., 1967. Calcareous nannoplankton from the Tertiary of Alabama. Micropaleontology, 13(2):163-182.

MacKenzie, D. T., III, and Wise, S. W., Jr., 1983. Paleocene and Eocene calcareous nannofossils from Deep Sea Drilling Project Legs 25 and 40, south and east of Africa. In Ludwig, W. J., Krasheninnikov, V. A., et al., Init. Repts. DSDP, 71: Washington (U.S. Govt. Printing Office), 1141-1180.

Martini, E., 1958. Discoasteriden und verwandte Formen in NW-deutschen Eozän (Coccolithophorida). 2. Stratigraphische Auswertung. Senckenb. Lethaea, 40:137-157.

Martini, E., and Müller, C., 1986. Current Tertiary and Quaternary calcareous nannoplankton stratigraphy and correlations. News. Strat., 16(2):99-112.

Miller, K. G., Gradstein F. M., and Berggren, W. A., 1982. Late Cretaceous to early Tertiary agglutinated benthic foraminifera in the Labrador Sea. Micropaleontology, 28(1):1-30.

Müller, C., 1970. Nannoplankton aus dem Mittel-Oligozän von Norddeutschland und Belgien. N. Jahr. Geol. Palaont., Abh., 135(1):82101.

1976. Tertiary and Quaternary calcareous nannoplankton in the Norwegian-Greenland Sea, DSDP, Leg 38. In Talwani, M., Udintsev, G., et al., Init. Repts., DSDP, 38: Washington (U.S. Govt. Printing Office), 823-841.

1979. Calcareous nannofossils from the North Atlantic (Leg 48). In Montadert, L., Roberts, D. G., et al., Init. Repts. DSDP, 48: Washington (U.S. Govt. Printing Office), 589-639.

, 1985. Biostratigraphic and paleoenvironmental interpretation of the Goban Spur region based on a study of calcareous nannoplankton. In de Graciansky, P. C., Poag, C. W., et al., Init. Repts. DSDP, 80: Washington (U.S. Govt. Printing Office), 573-599.

Okada, H., and Bukry, D., 1980. Supplementary modification and introduction of code numbers to the low-latitude coccolith biostratigraphic zonation (Bukry, 1973; 1975). Mar. Micropaleontol., 5(3): 321-325.

Okada, H., and Thierstein, H. R., 1979. Calcareous nannoplanktonLeg 43, Deep Sea Drilling Project. In Tucholke, B. E., Vogt, P. R., et al., Init. Repts. DSDP, 43: Washington (U.S. Govt. Printing Office), 507-573.

Parker, M. E., Clark, M., and Wise, S. W., Jr., 1985. Calcareous nannofossils of Deep Sea Drilling Project Sites 558 and 563, North Atlantic Ocean: biostratigraphy and the distribution of Oligocene braarudosphaerids. In Bougault, H., Cande, S. C., et al., Init. Repts. DSDP, 82: Washington (U.S. Govt. Printing Office), 559-589.
Perch-Nielsen, K., 1968. Beobachtungen im Elektronenmikroskop an Micrantholithus mirabilis und Marthasterites obscurus (Nannoplankton). Medd. Dansk Geol. Foren. Kovenhavn, 18:251-254.

1972. Remarks on Late Cretaceous to Pleistocene coccoliths from the North Atlantic. In Laughton, A. S., Berggren, W. A., et al., Init. Repts. DSDP, 12: Washington (U.S. Govt. Printing Office), 1003-1069.

1977. Albian to Pleistocene calcareous nannofossils from the western South Atlantic, DSDP Leg 39. In Supko, P. R., Perch-Nielsen, K., et al., Init. Repts. DSDP, 39: Washington (U.S. Govt. Printing Office), 699-823.

, 1985. Cenozoic calcareous nannofossils. In Bolli, H. M., Saunders, J. B., and Perch-Nielsen, K. (Eds.), Plankton Stratigraphy: Cambridge (Cambridge University Press), 427-554.

Proto Decima, F., Medizza, F., and Todesco, L., 1978. Southeastern Atlantic Leg 40 calcareous nannofossils. In Bolli, H. M., Ryan, W.B.F., et al., Init. Repts. DSDP, 40: Washington (U.S. Govt. Printing Office), 571-634.

Srivastava, S. P., Arthur, M., et al., 1987. Proc. ODP, Init. Repts., 105: College Station, TX (Ocean Drilling Program).

Takayama, T., and Sato, T., 1987. Coccolith biostratigraphy of the North Atlantic Ocean, Deep Sea Drilling Project Leg 94. In Ruddiman, W. F., Kidd, R. B., Thomas, E., et al., Init. Repts. DSDP, 94: Washington (U.S. Govt. Printing Office), 651-702.

Wise, S. W., Jr., 1983. Mesozoic and Cenozoic calcareous nannofossils recovered by Deep Sea Drilling Project Leg 71 in the Falkland Plateau region, southwest Atlantic Ocean. In Ludwig, W. J., Krasheninnikov, V. A., et al., Init. Repts. DSDP, 71: Washington (U.S. Govt. Printing Office), 481-550.

Wise, S. W., Jr., and Mostajo, E. L., 1983. Correlation of Eocene-Oligocene calcareous nannofossil assemblages from piston cores taken near Deep Sea Drilling Sites 511 and 512, southwest Atlantic Ocean. In Ludwig, W. J., Krasheninnikov, V. A., et al., Init. Repts. DSDP, 71: Washington (U.S. Govt. Printing Office), 1171-1180.

Date of initial receipt: 8 June 1987

Date of acceptance: 6 March 1988

Ms B105-131

List of species considered here, arranged alphabetically by genus and species.

Birkelundia arenosa Perch-Nielsen (1971)

Birkelundia staurion (Bramlette and Sullivan, 1961) Perch-Nielsen (1971)

Blackites spinosus (Deflandre and Fert, 1954) Hay and Towe (1962)

Braarudosphaera bigelowi (Gran and Braarud, 1935) Deflandre (1947)

Calcidiscus protoannulus (Gartner, 1971) Loeblich and Tappan (1978)

Campylosphaera dela (Bramlette and Sullivan, 1961) Hay and Mohler (1967)

Cepekiella lumina (Sullivan, 1965) Bybell (1975)

Chiasmolithus altus Bukry and Percival (1971)

Chiasmolithus bidens (Bramlette and Sullivan, 1961) Hay and Mohler (1967)

Chiasmolithus consuetus (Bramlette and Sullivan, 1961) Hay and Mohler (1967)

Chiasmolithus eograndis Perch-Nielsen (1971)

Chiasmolithus expansus (Bramlette and Sullivan, 1961) Gartner (1970)

Chiasmolithus gigas (Bramlette and Sullivan, 1961) Radomski (1968)

Chiasmolithus grandis (Bramlette and Riedel, 1954) Radomski (1968)

Chiasmolithus nitidus Perch-Nielsen (1971)

Chiasmolithus oamaruensis (Deflandre, 1954) Hay, Mohler, and Wade (1966)

Chiasmolithus solitus (Bramlette and Sullivan, 1961) Locker (1968)

Chiasmolithus titus Gartner (1970)

Chiphragmalithus armatus Perch-Nielsen (1971)

Coccolithus pelagicus (Wallich, 1877) Schiller (1930)

Corannulus germanicus Stradner (1962)

Coronocyclus nitescens (Kamptner, 1963) Bramlette and Wilcoxon (1967)

Craterolithus hoerstgensis Muller (1970) Firth (in press)

Cribrocentrum reticulatum (Gartner and Smith, 1967) Perch-Nielsen (1971)

Cruciplacolithus cribellum (Bramlette and Sullivan, 1961) Romein (1979)

Cruciplacolithus inseadus Perch-Nielsen (1969)

Cruciplacolithus latipons Romein (1979) 
Cruciplacolithus mutatus Perch-Nielsen (1971)

Cyclicargolithus abisectus (Muller, 1970) Wise (1973)

Cyclicargolithus floridanus (Roth and Hay

in Hay et al., 1967) Bukry (1971)

Daktylethra punctulata Gartner in Gartner and Bukry (1969)

Discoaster adamanteus Bramlette and Wilcoxon (1967)

Discoaster barbadiensis Tan (1927)

Discoaster bifax Bukry (1971)

Discoaster binodosus Martini (1958)

Discoaster binodosus ssp. hirundinus Martini (1958)

Discoaster sp. cf. D. wemmelensis Achuthan and Stradner (1969)

Discoaster cruciformis Martini (1958)

Discoaster deflandrei Bramlette and Riedel (1954)

Discoaster distinctus Martini (1958)

Discoaster gemmifer Stradner (1961)

Discoaster kuepperi Stradner (1959)

Discoaster lodoensis Bramlette and Riedel (1954)

Discoaster saipanensis Bramlette and Riedel (1954)

Discoaster spp.

Discoaster sublodoensis Bramlette and Sullivan (1961)

Discoaster tani Bramlette and Riedel (1954)

Discoaster tani ssp. nodifer Bramlette and Riedel (1954)

Discoaster tani ssp. ornatus Bramlette and Wilcoxon (1967)

Ellipsolithus lajollaensis Bukry and Percival (1971)

Ellipsolithus macellus (Bramlette and Sullivan, 1961) Sullivan (1964)

Ericsonia fenestrata (Deflandre and Fert, 1954) Stradner in Stradner and Edwards (1968)

Ericsonia formosa (Kamptner, 1963) Haq (1971)

Genus and Species Indeterminate

Goniolithus fluckigeri Deflandre (1957)

Helicosphaera bramlette (Muller, 1970) Jafar and Martini (1975)

Helicosphaera compacta Bramlette and Wilcoxon (1967)

Helicosphaera dinesenii Perch-Nielsen (1971)

Helicosphaera elongata Theodoridis (1984)

Helicosphaera euphratis Haq (1966)

Helicosphaera gartneri Theodoridis (1984)

Helicosphaera heezenii (Bukry, 1971a) Jafar and Martini (1975)

Helicosphaera intermedia Martini (1965)

Helicosphaera lophota (Bramlette and Sullivan, 1961) Locker (1973)

Helicosphaera obliqua Bramlette and Wilcoxon (1967)

Helicosphaera sp. cf. $H$. orientalis Black (1971)

Helicosphaera papillata (Bukry and Bramlette, 1969) Jafar and Martini (1975)

Helicosphaera perch-nielsenae (Haq, 1971) Jafar and Martini (1975)

Helicosphaera recta $\mathrm{Haq}$ (1966)

Helicosphaera reticulata Bramlette and Wilcoxon (1967)

Helicosphaera seminulum Bramlette and Sullivan (1961)

Imperiaster obscurus (Martini, 1958) Martini (1970)

Isthmolithus recurvus Deflandre in Deflandre and Fert (1954)

Lanternithus minutus Stradner (1962)

Lithostromation operosum (Deflandre in Deflandre and Fert 1954) Bybell (1975)

Lithostromation perdurum Deflandre (1942)

Lithostromation reginum (Stradner, 1962) Bybell (1975)

Lophodolithus mochloporus Deflandre in Deflandre and Fert (1954)

Lophodolithus nascens Bramlette and Sullivan (1961)

Lophodolithus reniformis Bramlette and Sullivan (1961)

Markalius inversus (Deflandre in Deflandre and Fert, 1954) Bramlette and Martini (1964)

Micrantholithus mirabilis Locker (1965)

Micrantholithus spp.

Nannotetrina cristata (Martini, 1958) Perch-Nielsen (1971)

Neochiastozygus cearae Perch-Nielsen (1977)

Neochiastozygus junctus (Bramlette and Sullivan, 1961) Perch-Nielsen (1971)

Neococcolithes dubius (Deflandre in Deflandre and Fert, 1954) Black (1967)

Neococcolithes protenus (Bramlette and Sullivan, 1961) Black (1967)

Pedinocyclus larvalis (Bukry and Bramlette ex Bukry and Bramlette, 1971) Loeblich and Tappan (1973)

Pemma spp.

Pontosphaera multipora (Kamptner ex Deflandre, 1959) Roth (1970)

Pontosphaera spp.

Pyrocyclus hermosus Roth and Hay in Hay et al. (1967)

Pyrocyclus inversus Hay and Towe (1962)

Pyrocyclus orangensis (Bukry, 1971) Backman (1980)
Reticulofenestra bisecta (Hay, Mohler, and Wade, 1966) Roth (1970)

Reticulofenestra daviesii (Haq) Haq (1971)

Reticulofenestra dictyoda (Deflandre and Fert, 1954) Stradner in Stradner and Edwards (1968)

Reficulofenestra lockeri Muller (1970)

Reticulofenestra onusta (Perch-Nielsen, 1971) Wise (1983)

Reticulofenestra spp. (small)

Reticulofenestra umbilica (Levin, 1965) Martini and Ritzkowski (1968)

Rhabdosphaera inflata Bramlette and Sullivan (1961)

Rhabdosphaera pseudomorionum Locker (1967)

Rhabdosphaera tenuis Bramlette and Sullivan (1961)

Rhabdosphaera vitrea (Deflandre in Deflandre and Fert, 1954) Bramlette and Sullivan (1961)

Sphenolithus sp. cf. S. anarrhopus

Sphenolithus ciperoensis Bramlette and Wilcoxon (1967)

Sphenolithus conspicuus Martini (1976)

Sphenolithus delphix Bukry (1973)

Sphenolithus dissimilis Bukry and Percival (1971)

Sphenolithus distentus (Martini, 1965) Bramlette and Wilcoxon (1967)

Sphenolithus editus Perch-Nielsen in Perch-Nielsen et al. (1978)

Sphenolithus furcatolithoides Locker (1967)

Sphenolithus furcatolithoides labradorensis $\mathrm{n}$. subsp.

Sphenolithus moriformis (Bronnimann and Stradner, 1960) Bramlette and Wilcoxon (1967)

Sphenolithus obtusus Bukry (1971)

Sphenolithus predistentus Bramlette and Wilcoxon (1967)

Sphenolithus radians Deflandre in Grasse (1952)

Sphenolithus sp. 1

Sphenolithus spiniger Bukry (1971)

Sphenolithus tribulosus Roth (1970)

Striatococcolithus pacificanus Bukry (1971)

Toweius callosus Perch-Nielsen (1971)

Toweius? gammation (Bramlette and Sullivan, 1961) Romein (1979)

Toweius magnicrassus (Bukry, 1971) Romein (1979)

Toweius occultatus (Locker, 1967) Perch-Nielsen (1971)

Toweius pertusus (Sullivan, 1965) Romein (1979)

Transversopontis fimbriatus (Bramlette and Sullivan, 1961) Locker (1968)

Transversopontis pulcher (Deflandre in Deflandre and Fert, 1954) PerchNielsen (1967)

Transversopontis pulcheroides (Sullivan, 1964) Baldi-Beke (1971)

Transversopontis sigmoidalis Locker (1967)

Tribrachiatus orthostylus Shamrai (1963)

Zygrhablithus bijugatus (Deflandre in Deflandre and Fert, 1954) Deflandre (1959)

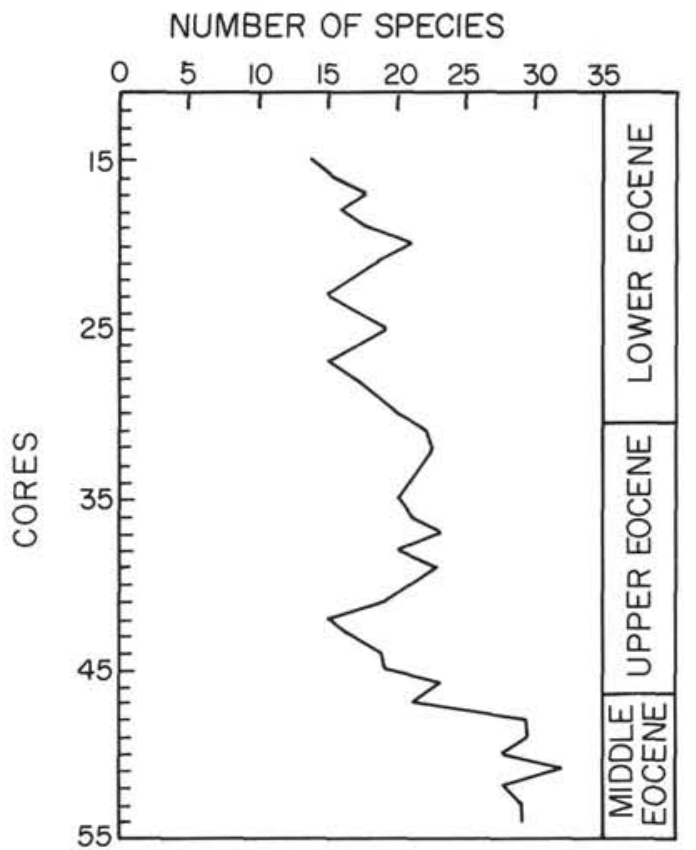

Figure 3. Species abundances per core through the middle Eocene to lower Oligocene in Hole 647A. Species abundances per core were calculated by averaging the number of species per sample in each core. 
Table 5. Eocene-Oligocene calcareous nannofossils from Hole 112.

\begin{tabular}{|c|c|c|c|c|c|c|c|c|c|c|c|c|c|c|c|c|c|c|c|c|c|c|c|c|c|}
\hline Age & $\begin{array}{c}\text { Zone } \\
\text { (Martini, 1971) }\end{array}$ & $\begin{array}{l}\text { Core-section } \\
\text { interval }(\mathrm{cm})\end{array}$ & 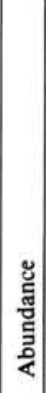 & 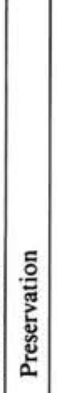 & 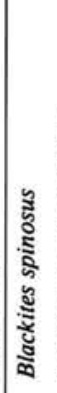 & 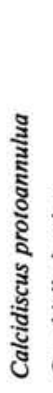 & : & 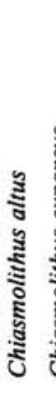 & 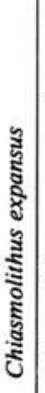 & 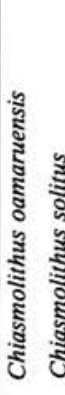 & 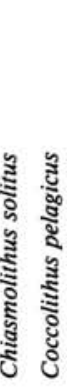 & 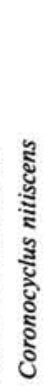 & 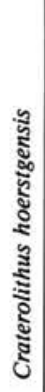 & 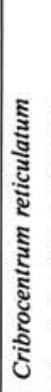 & 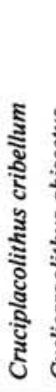 & 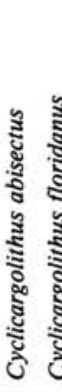 & 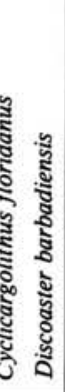 & 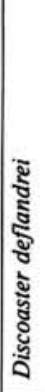 & 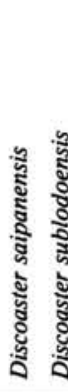 & 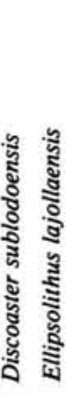 & 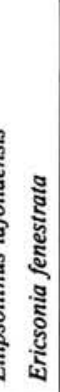 & 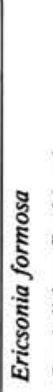 & 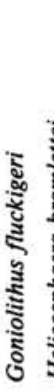 & 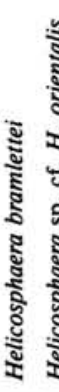 & 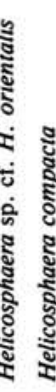 \\
\hline \multirow[t]{2}{*}{$\begin{array}{c}\text { early } \\
\text { Oligocene }\end{array}$} & NP23 & $\begin{array}{l}5-1,85-89 \\
5-2,90-94 \\
5-3,116-120 \\
5-4,95-99 \\
5-5,95-99 \\
5-6,89-93 \\
6-4,96-100 \\
7-2,122-126 \\
8-1,107-109 \\
9-2,90-94 \\
9-3,94-98 \\
9-4,94-98 \\
9-5,94-98 \\
10, C C \\
11-1,127-131 \\
11-2,102-106 \\
11-3,108-112 \\
11-4,69-73\end{array}$ & $\begin{array}{l}\text { C } \\
\text { C } \\
\text { A } \\
\text { C } \\
\text { A } \\
\text { A } \\
\text { A } \\
\text { A } \\
\text { A } \\
\text { F } \\
\text { F } \\
\text { F } \\
\text { C } \\
\text { A } \\
\text { A } \\
\text { A } \\
\text { A } \\
\text { A }\end{array}$ & $\begin{array}{l}\text { M } \\
\text { M } \\
\text { M } \\
\text { P } \\
\text { M } \\
\text { G } \\
\text { M } \\
\text { G } \\
\text { G } \\
\text { P } \\
\text { P } \\
\text { M } \\
\text { M } \\
\text { G } \\
\text { G } \\
\text { G } \\
\text { M } \\
\text { M }\end{array}$ & $\begin{array}{l}\cdot \\
: \\
\cdot \\
\cdot \\
: \\
: \\
: \\
\cdot \\
\cdot \\
: \\
: \\
: \\
.\end{array}$ & $\begin{array}{l}: \\
: \\
: \\
: \\
: \\
: \\
: \\
: \\
: \\
: \\
: \\
:\end{array}$ & 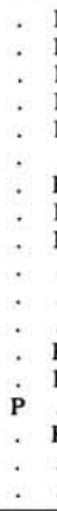 & $\begin{array}{l}\mathrm{F} \\
\mathrm{F} \\
\mathrm{F} \\
\mathrm{F} \\
\mathrm{F} \\
\dot{\mathrm{R}} \\
\mathrm{F} \\
\mathrm{F} \\
\dot{.} \\
\dot{\mathrm{R}} \\
\mathrm{F} \\
\dot{\mathrm{R}} \\
\dot{.} \\
\end{array}$ & 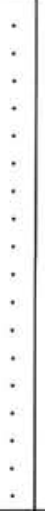 & 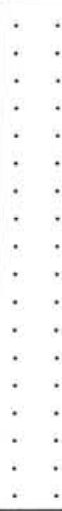 & 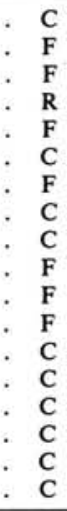 & $\begin{array}{l}: \\
: \\
: \\
: \\
: \\
: \\
: \\
: \\
: \\
:\end{array}$ & $\begin{array}{l}\dot{.} \\
\dot{\mathrm{P}} \\
\dot{\mathrm{P}} \\
\dot{.} \\
\dot{\mathrm{P}} \\
\dot{.} \\
\dot{.} \\
\dot{.} \\
\dot{.} \\
\dot{.} \\
\dot{.} \\
\end{array}$ & $\begin{array}{l}: \\
: \\
: \\
\vdots \\
\vdots \\
\vdots \\
: \\
: \\
: \\
\end{array}$ & 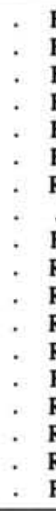 & $\begin{array}{ll}\mathrm{F} \\
\mathrm{F} \\
\mathrm{F} \\
\mathrm{F} \\
\mathrm{F} \\
\mathrm{F} \\
\mathrm{F} \\
\mathrm{R} \\
\mathrm{F} \\
\mathrm{F} \\
\mathrm{R} \\
\mathrm{R} \\
\mathrm{R} \\
\mathrm{R} \\
\mathrm{F} \\
\mathrm{F} \\
\mathrm{R} \\
\mathrm{F} \\
\mathrm{R}\end{array}$ & $\begin{array}{l}\mathrm{C} \\
\mathrm{C}: \\
\mathrm{C} \\
\mathrm{F} \\
\mathrm{F}: \\
\mathrm{C}: \\
\mathrm{C}: \\
\mathrm{C}: \\
\mathrm{C}: \\
\mathrm{F}: \\
\mathrm{F}: \\
\mathrm{F}: \\
\mathrm{F}: \\
\mathrm{C}\end{array}$ & 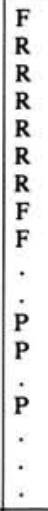 & 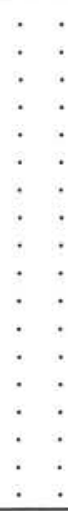 & $\begin{array}{l}: \\
: \\
: \\
: \\
: \\
: \\
: \\
: \\
:\end{array}$ & 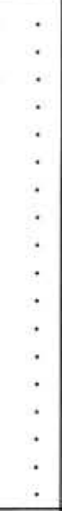 & $\begin{array}{l}\cdot \\
: \\
: \\
: \\
: \\
\vdots \\
: \\
: \\
: \\
: \\
\end{array}$ & 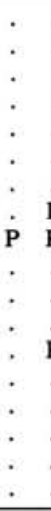 & 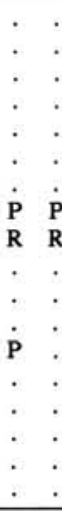 & 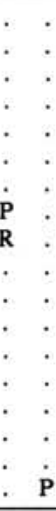 \\
\hline & NP22 & $12-1,44-48$ & $\mathbf{A}$ & M & . & . &. & . &. & $\mathbf{R}$ & . $\mathrm{C}$ &. &. & . & . &. & C. &. & . & . & $\mathrm{P}$ & . & .1 & $\mathbf{P}$ & . \\
\hline $\begin{array}{l}\text { late } \\
\text { Eocene }\end{array}$ & $\begin{array}{c}\text { NP18 } \\
\text { to } \\
\text { NP20 }\end{array}$ & $\begin{array}{l}13-1,120-124 \\
13-2,123-127 \\
13-3,118-122 \\
13-4,120-124 \\
13-5,120-124 \\
\end{array}$ & $\begin{array}{l}\text { A } \\
\text { A } \\
\text { A } \\
\text { A } \\
\text { C } \\
\end{array}$ & \begin{tabular}{l|}
$\mathbf{M}$ \\
$\mathbf{M}$ \\
$\mathbf{M}$ \\
$\mathbf{M}$ \\
$\mathbf{M}$ \\
\end{tabular} & $\begin{array}{l}\mathrm{F} \\
\dot{\mathrm{F}} \\
\mathrm{F} \\
\end{array}$ & $\begin{array}{l}\dot{\mathrm{P}} \\
\dot{ } \\
\dot{ }\end{array}$ & $\begin{array}{l}\mathrm{R} \\
\dot{\mathrm{P}} \\
\dot{ } \\
\dot{ }\end{array}$ & $:$ & $:$ & $\begin{array}{l}\mathrm{F} \\
\mathrm{F} \\
\mathrm{F} \\
\mathrm{F} \\
\mathrm{F}\end{array}$ & 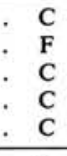 & $\begin{array}{l}\dot{\mathrm{R}} \\
\dot{ } \\
\dot{ }\end{array}$ & : & $\begin{array}{l}\mathrm{C} \\
\mathrm{C} \\
\mathrm{C} \\
\mathrm{C} \\
\mathrm{F} \\
\end{array}$ & $:$ & : & $\begin{array}{ll}F & R \\
R & P \\
R & P \\
F & R \\
F & \dot{R} \\
\end{array}$ & $\dot{:}:$ & $\begin{array}{l}\mathrm{F} \\
\mathrm{F} \\
\mathrm{F} \\
\mathrm{F} \\
\mathrm{F}\end{array}$ & $\dot{.}$ & $\begin{array}{l}\mathrm{P} \\
\dot{\mathrm{R}} \\
\mathrm{F} \\
\end{array}$ & $\begin{array}{l}\mathbf{R} \\
\mathbf{R} \\
\mathbf{F} \\
\mathbf{P} \\
\mathbf{R} \\
\end{array}$ & : & R. & : \\
\hline \multirow[t]{3}{*}{$\begin{array}{l}\text { middle } \\
\text { Eocene }\end{array}$} & NP17 & $\begin{array}{l}14-2,118-122 \\
14-3,110-114 \\
14-4,100-104 \\
14-5,103-107 \\
\end{array}$ & $\begin{array}{l}\mathrm{A} \\
\mathrm{A} \\
\mathrm{F} \\
\mathrm{C}\end{array}$ & \begin{tabular}{|l|}
$\mathrm{M}$ \\
$\mathrm{M}$ \\
$\mathrm{M}$ \\
$\mathrm{M}$ \\
\end{tabular} & $\begin{array}{l}\dot{\mathrm{R}} \\
\dot{\mathrm{R}} \\
\end{array}$ & $\dot{.}$. & $\dot{.}$ & 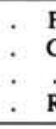 & \begin{tabular}{l|}
$\mathrm{F}$ \\
$\mathrm{C}$ \\
$\dot{\mathrm{R}}$ \\
\end{tabular} & 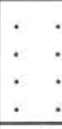 & $\begin{array}{l}\mathrm{C} \\
\text {. } \\
\mathrm{F} \\
\mathrm{R} \\
\mathrm{F}\end{array}$ & : & $\dot{.}$ & $\begin{array}{l}\mathrm{C} \\
\mathrm{C} \\
\mathrm{F} \\
\mathrm{F} \\
\end{array}$ & $\dot{\mathrm{P}}$ & $\dot{.}$ & $\begin{array}{ll} & \mathbf{R} \\
\dot{\mathrm{R}} & \mathrm{F} \\
\dot{\mathrm{R}} & \dot{\mathrm{R}} \\
\end{array}$ & \begin{tabular}{|l}
. \\
$\dot{.}$ \\
\end{tabular} & $\begin{array}{l}\mathrm{F} \\
\mathrm{R} \\
\dot{\mathrm{P}} \\
\end{array}$ & $\dot{0} \cdot$ & $\begin{array}{c}\mathbf{P} \\
\mathbf{R} \\
\dot{\mathbf{R}} \\
\end{array}$ & \begin{tabular}{|l}
$\mathbf{R}$ \\
$\mathbf{R}$ \\
$\mathbf{R}$ \\
. \\
\end{tabular} & $\dot{.}$ & : & . \\
\hline & NP15 & $15-1,6-10$ & $\mathbf{A}$ & M & . &. &. &.$\quad$. & . & . $\mathrm{F}$ & $\mathrm{F} \quad \mathrm{F}$ & . & . &. & . & . & . $\mathbf{R}$ & . & . $\mathrm{P}$ & $P \quad P$ & . & $\mathbf{R}$ & . & . & . \\
\hline & NP14 & $15-6,110-114$ & $\mathbf{A}$ & $\mathbf{M}$ & . & . & $\mathbf{P}$ & . $\mathrm{R}$ & $\mathbf{R}$ & . $\mathrm{F}$ & $\mathrm{F} \quad \mathrm{C}$ & . & . & . & . &. & . $\mathbf{P}$ & . & . & $\begin{array}{ll}R & P \\
\end{array}$ & . & $\mathbf{R}$ & . & . & . \\
\hline$?$ & Barren & $16-1,85-89$ & B & . & . & . & . &. &. & . . & . & . & . &. & . & . & & . & . & . & . & . & & . & . \\
\hline
\end{tabular}

Abundances are characterized by $\mathbf{A}=$ abundant, $\mathrm{C}=$ common, $\mathrm{F}=$ few, $\mathrm{R}=$ rare, $\mathrm{r}=$ reworked, and $\mathbf{B}=$ barren.

Preservation is characterized by $\mathrm{G}=\operatorname{good}, \mathrm{M}=$ moderate, and $\mathrm{P}=$ poor. 
Table 5 (continued).

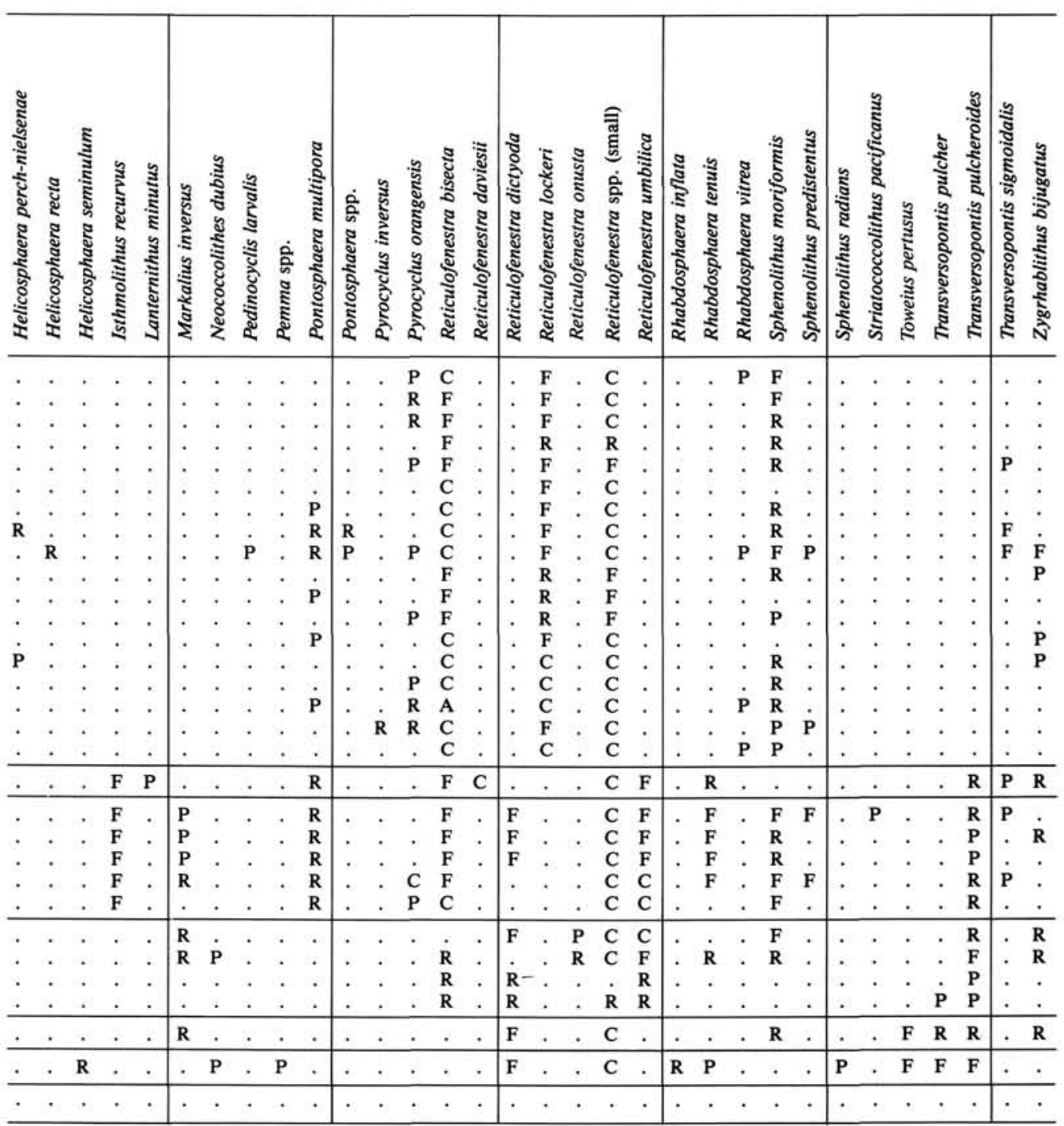




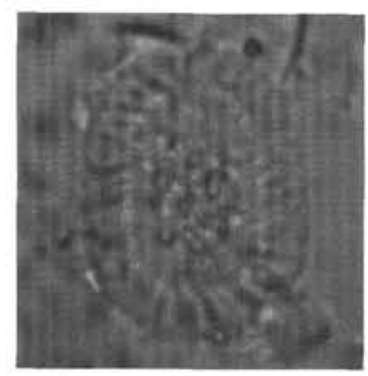

1

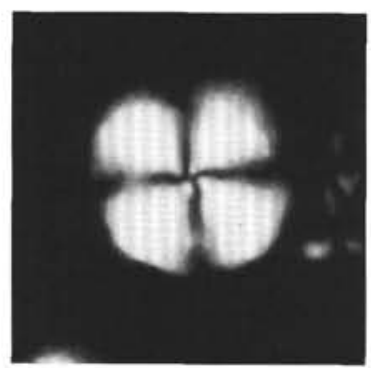

5

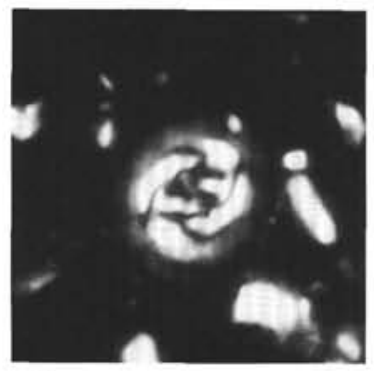

8

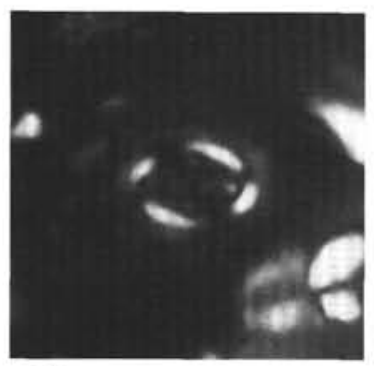

12

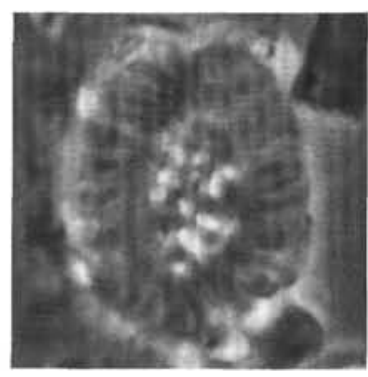

2

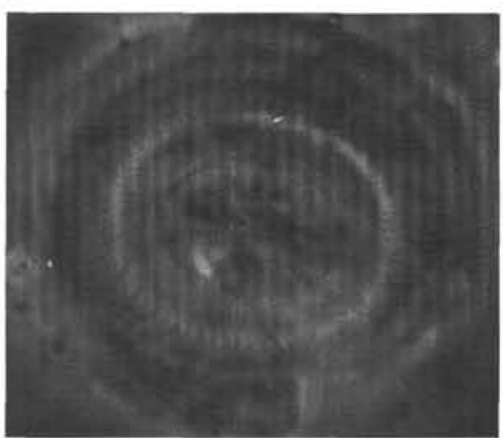

6

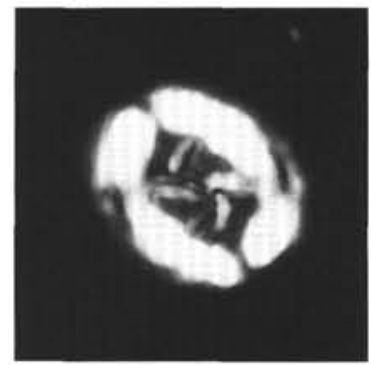

9

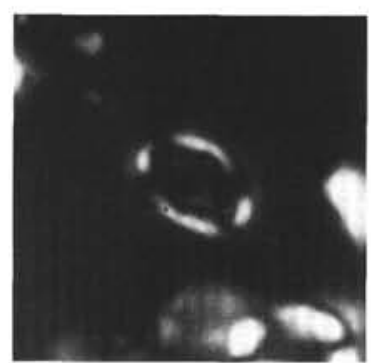

13

10

14

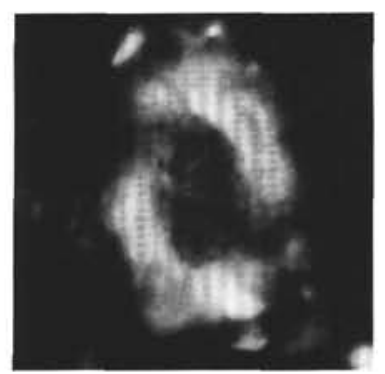

3

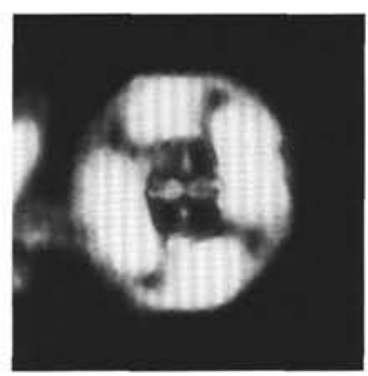

4

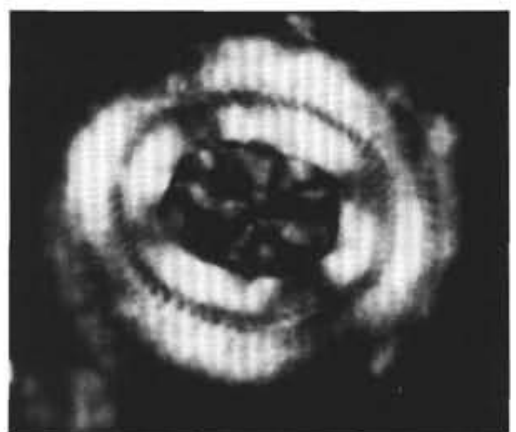

7
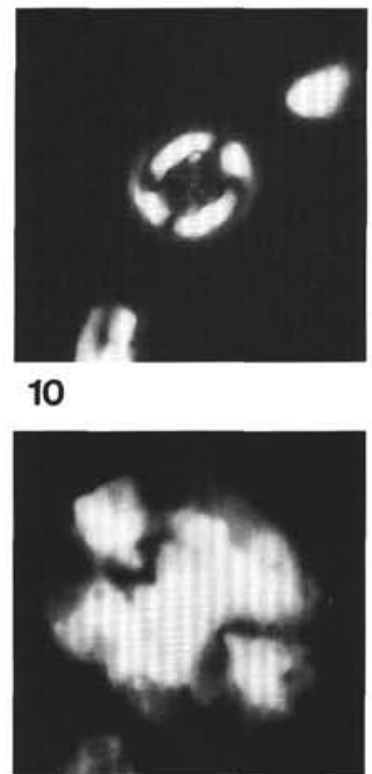

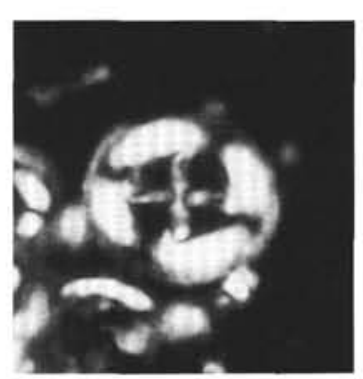

11

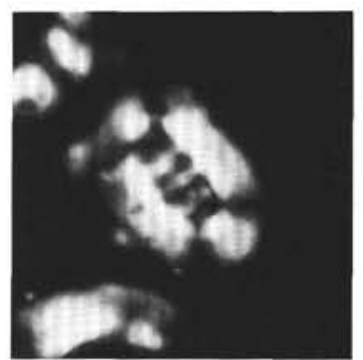

15

Plate 1. Eocene nannofossils. 1-3. Birkelundia arenosa, Sample 105-647A-49R-1, 91-93 cm, 2400X. 4. Birkelundia staurion, Sample 105-647A62R-5, 87-89 cm, 2780X. 5. Cepekiella lumina, Sample 105-647A-48R-5, 90-92 cm, 3360X. 6 and 7. Chiasmolithus gigas, Sample 105-647A-63R1, 36-38 cm, 2530X. 8. Chiasmolithus nitidus, Sample 105-647A-63R-1, 36-38 cm, 2600X. 9. Chiasmolithus solitus, Sample 105-647A-53R-3, 26$28 \mathrm{~cm}, 3070 \mathrm{X}$. 10. Chiasmolithus titus, Sample 105-647A-53R-2, 29-31 cm, 2700X. 11. Cruciplacolithus mutatus, Sample 105-647A-63R-1, 36-38 $\mathrm{cm}, 2670 \mathrm{X}$. 12 and 13. Cruciplacolithus inseadus, Sample 105-647A-53R-2, 29-31 cm, 4320X. 14. Ellipsolithus macellus, Sample 105-647A-70R1, $47-49 \mathrm{~cm}, 2640 \mathrm{X}$. 15. Ellipsolithus lajollaensis, Sample 105-647A-62R-2, $83-85 \mathrm{~cm}, 2800 \mathrm{X}$. 


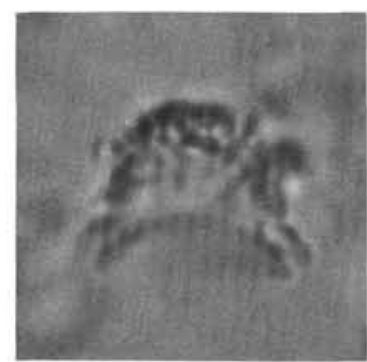

1

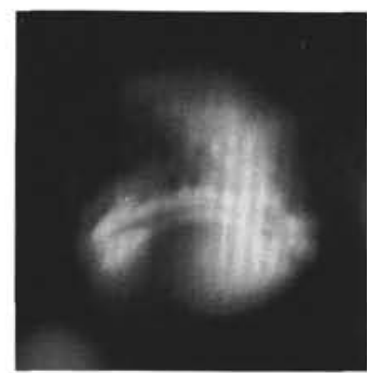

5

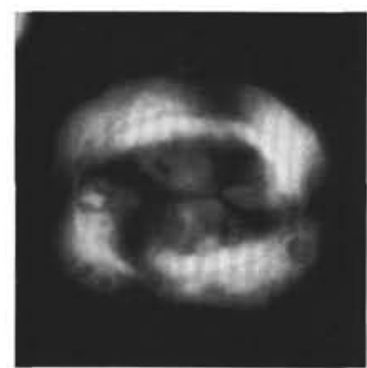

9

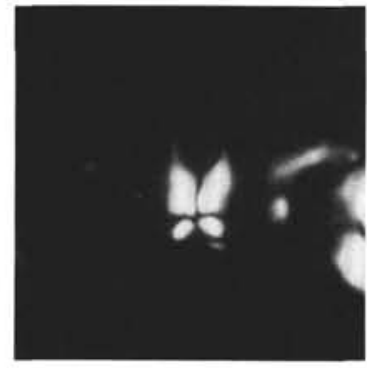

13

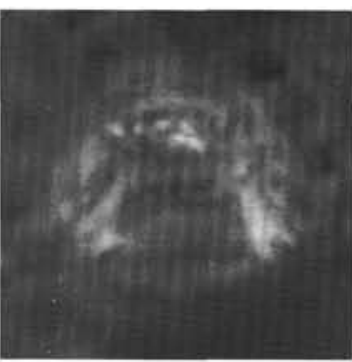

2

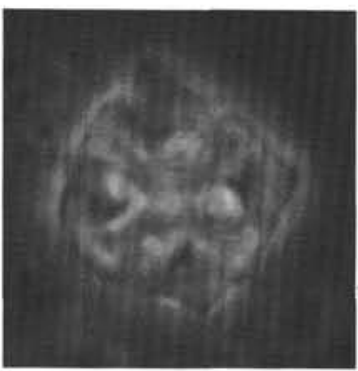

6

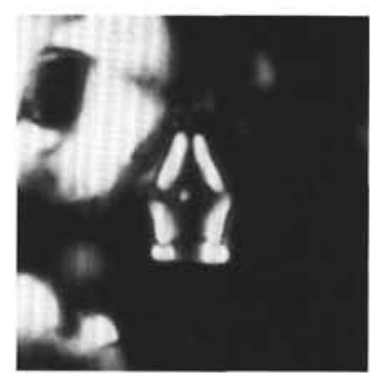

10

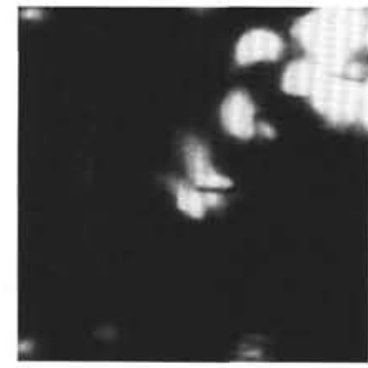

14

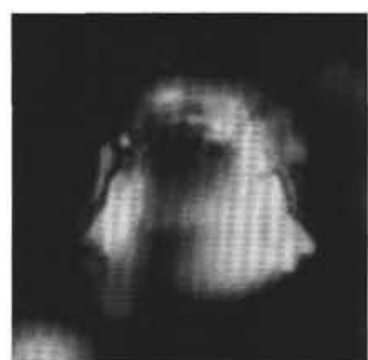

3

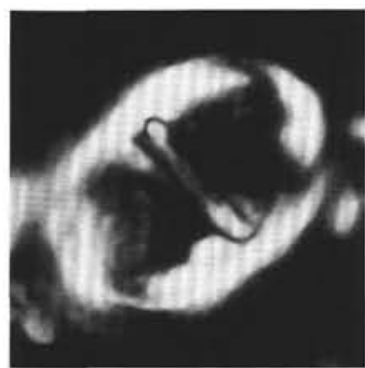

7

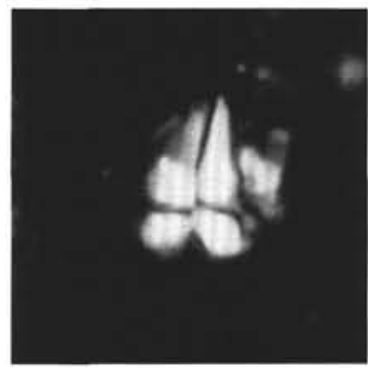

11

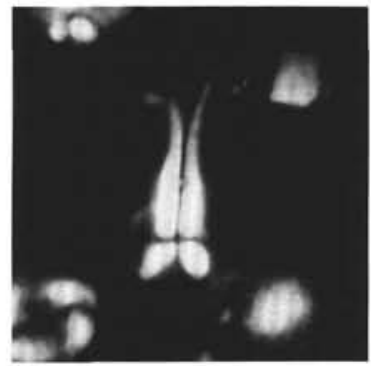

15

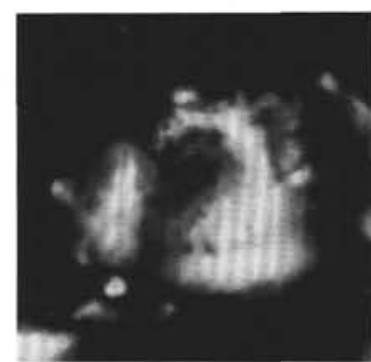

4

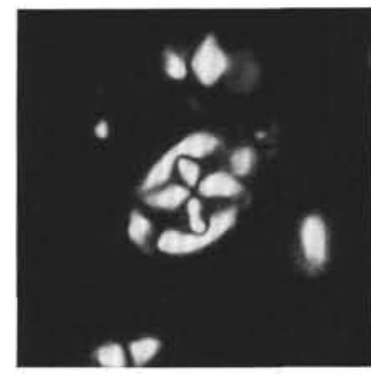

8

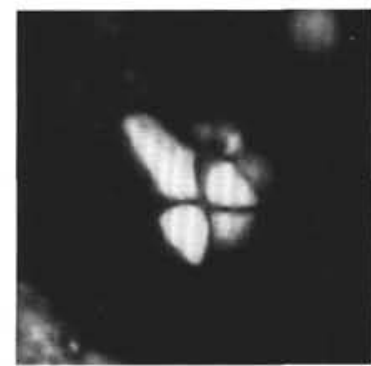

12

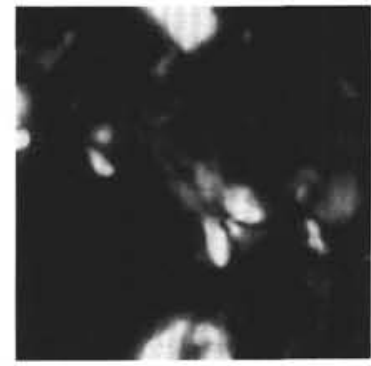

16

Plate 2. Eocene nannofossils. 1-5. Genus and Species indeterminate, Sample 105-647A-51R-4, 113-116 cm, 3000X. 6. Nannotetrina cristata, Sample 105-647A-62R-1, 82-84 cm, 2400X. 7. Neochiastozygus cearae, Sample 105-647A-70R-2, 47-49 cm, 2640X. 8. Neococcolithes protenus, Sample 105-647A-70R-1, 47-49 cm, 3200X. 9. Reticulofenestra onusta, Sample 105-647A-66R-2, 49-51 cm, 2240X. 10. Rhabdosphaera pseudomorionum, Section 105-647A-57R, CC, 2600X. 11 and 12. Sphenolithus sp. cf. S. annarhopus, Sample 105-647A-48R-5, 90-92 cm, 3400X. 11: Oblique angle to nicols; $12: 45^{\circ}$ to nicols. 13 and 14. Sphenolithus furcatolithoides, Sample 105-647A-62R-2, 83-85 cm, 2800X. 15 and 16. Sphenolithus furcatolithoides labradorensis n. subsp., holotype, Sample 105-647A-52R-2, 122-124 cm, 3200X. 


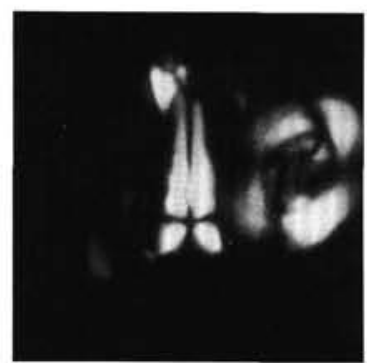

1

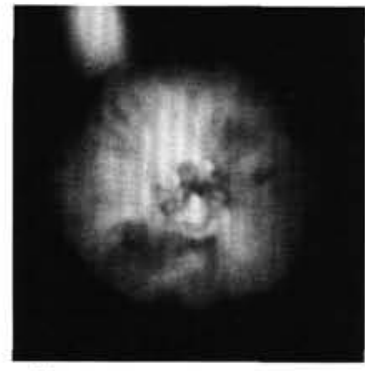

5

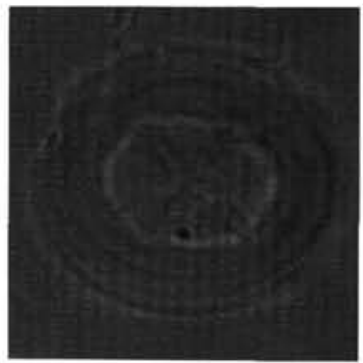

9

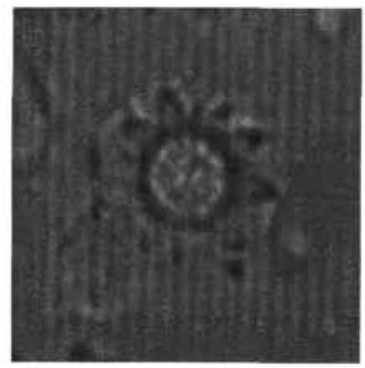

13

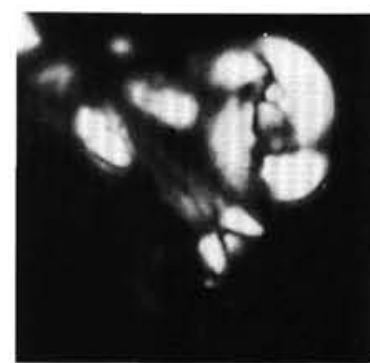

2

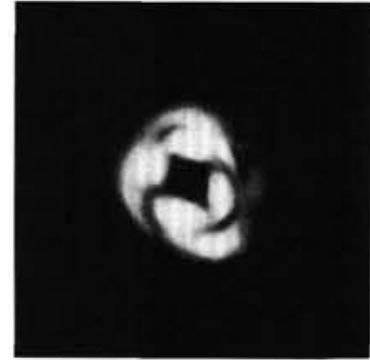

6

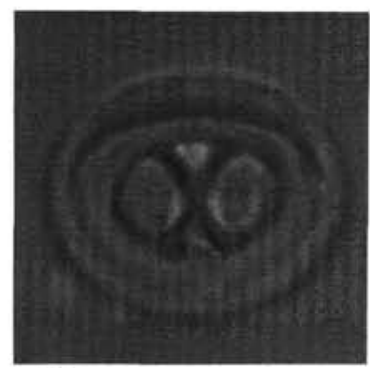

10

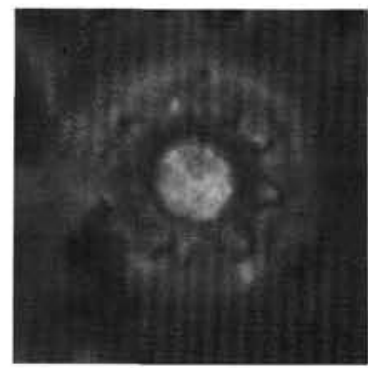

14

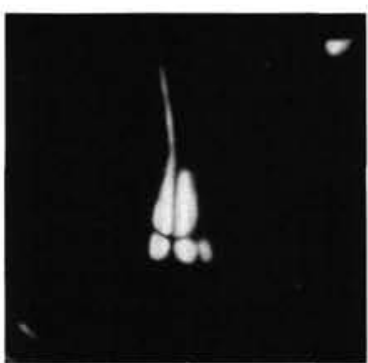

3

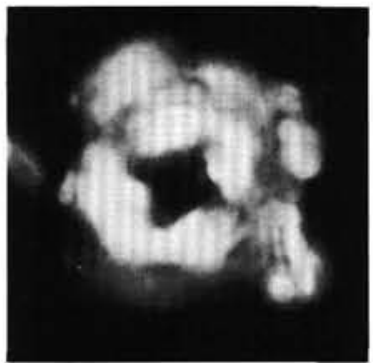

7

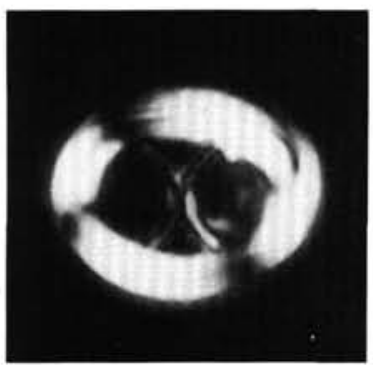

11

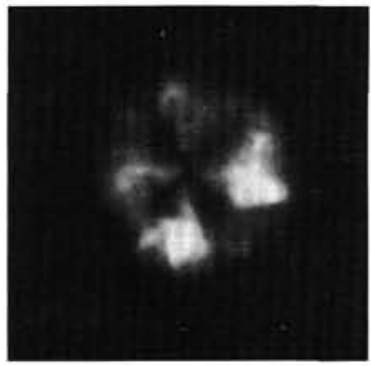

15

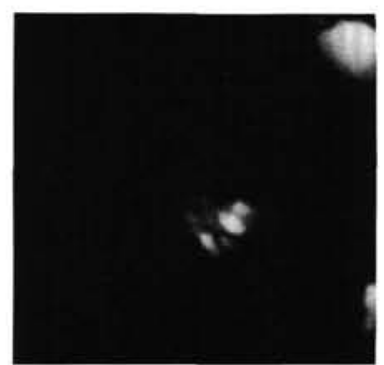

4

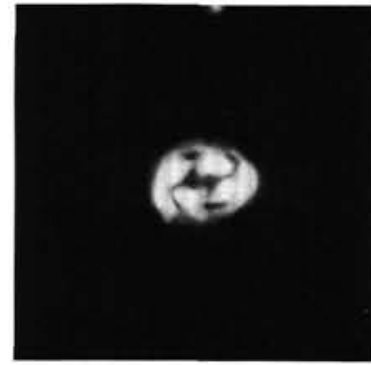

8

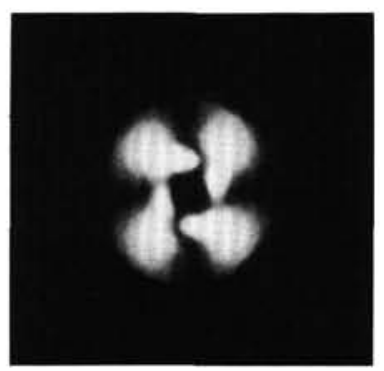

12

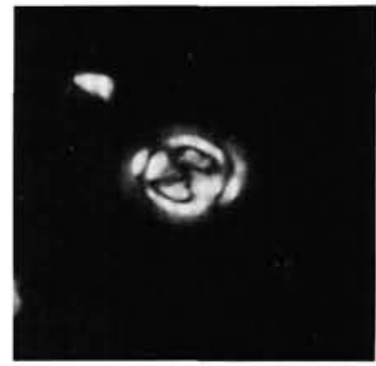

16

Plate 3. Eocene and Oligocene nannofossils. 1-4. Sphenolithus furcatolithoides labradorensis, n. subsp., paratypes, Sample 105-647A-53R-2, 29$31 \mathrm{~cm}(1,2: 2820 X ; 3,4: 2670 X$. 5. Striatococcolithus pacificanus, Sample 105-647A-68R-4, 36-38 cm, 2700X. 6. Toweius callosus, Sample 105647A-68R-3, 47-49 cm, 2560X. 7. Toweius magnicrassus, Sample 105-647A-66R-2, 49-51 cm, 2420X. 8. Toweius occultatus, Sample 105-647A68R-3, 47-49 cm, 2590X. 9. Chiasmolithus altus, Sample 105-647A-19R-4, 14-16 cm, 2470X. 10 and 11. Chiasmolithus oamaruensis, Sample 105-647A-30R-2, 15-17 cm, 2220X. 12. Cyclicargolithus floridanus, Sample 105-647A-21R-1, 67-69 cm, 2530X. 13-15. Craterolithus hoerstgensis, Sample 105-647A-19R-4, 14-16 cm, 2360X. 16. Ericsonia fenestrata, Sample 105-647A-53R-2, 29-31 cm, $2800 \mathrm{X}$. 


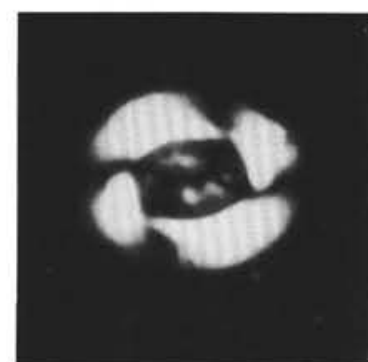

1

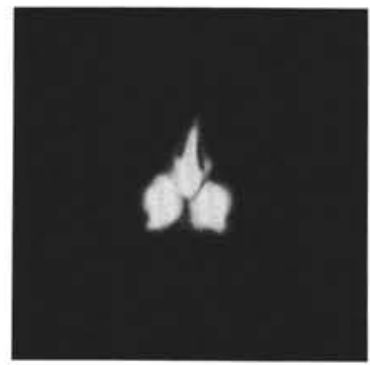

5

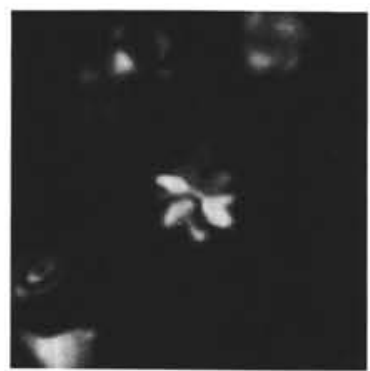

9

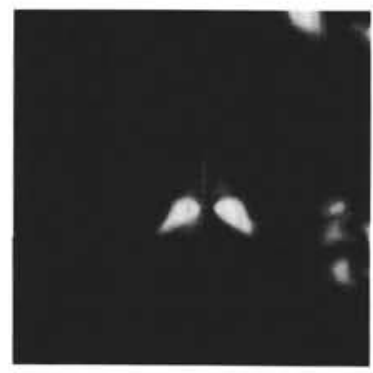

13

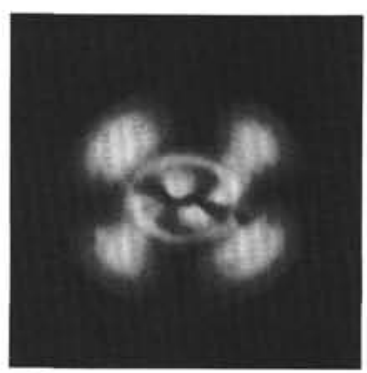

2

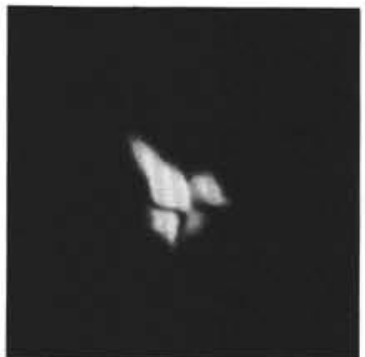

6

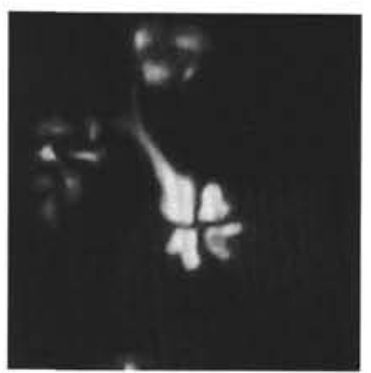

10

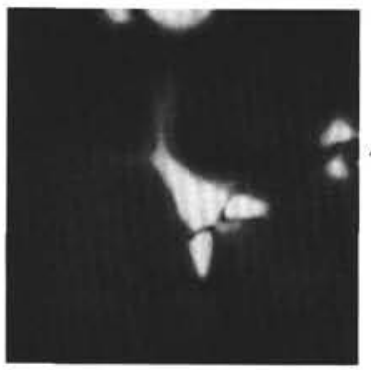

14

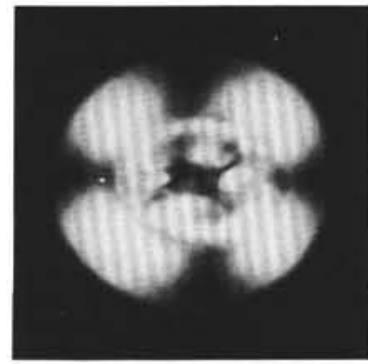

3

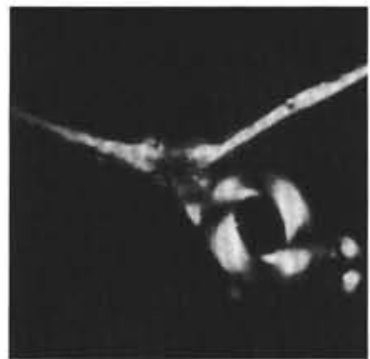

7

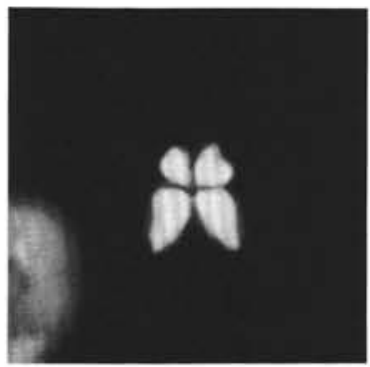

11

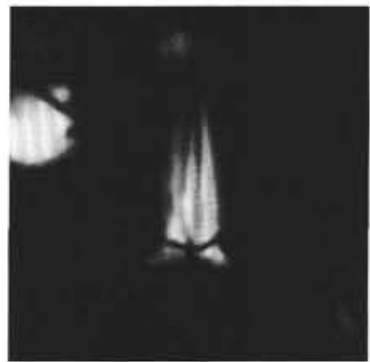

15

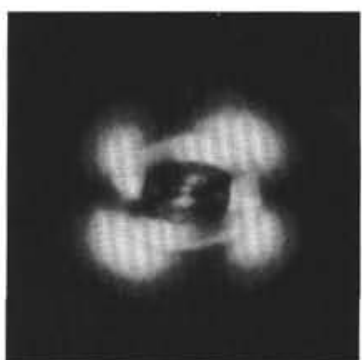

4

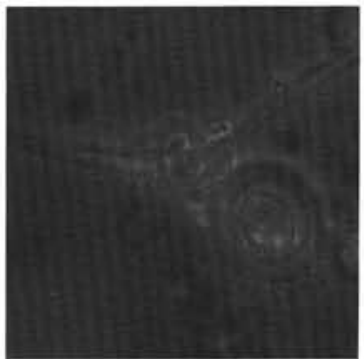

8

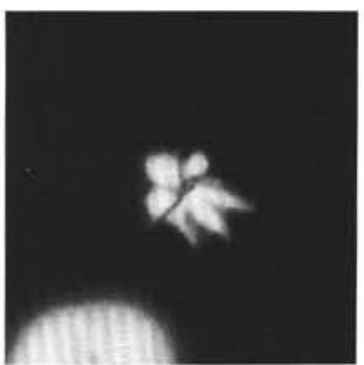

12

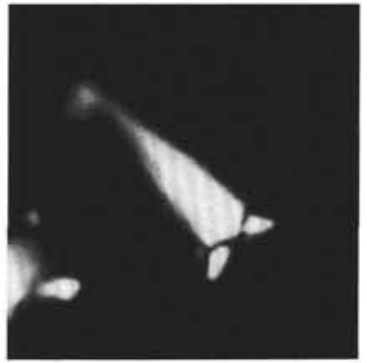

16

Plate 4. Oligocene nannofossils. 1. Reticulofenestra lockeri, Sample 105-647A-19R-4, 14-16 cm, 2510X. 2-4. Reticulofenestra bisecta; 2: Sample 105-647A-21R-1, 67-69 cm, 2330X; 3: Sample 105-647A-19R-4, 14-16 cm, 2550X; 4: Sample 105-647A-17R-4, 111-113 cm, 2230X. 5 and 6. Sphenolithus ciperoensis, Sample 105-647A-16R-3, 36-38 cm, 2600X. 7 and 8. Sphenolithus delphix, Sample 105-647A-19R-4, 14-16 cm, 1600X. 9 and 10. Sphenolithus sp. 1, Sample 105-647A-19R-1, 9-11 cm, 3330X. 11 and 12. Sphenolithus dissimilis, Sample 105-647A-16R-3, 36-38 cm, 3200X. 13 and 14. Sphenolithus distentus, Sample 105-647A-17R-4, 111-113 cm, 2860X. 15 and 16. Sphenolithus obtusus, Sample 105-647A25R-4, 61-63 cm, 2930X. 


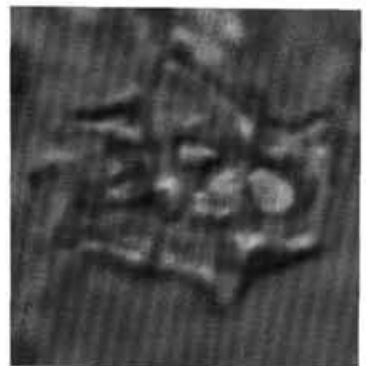

1

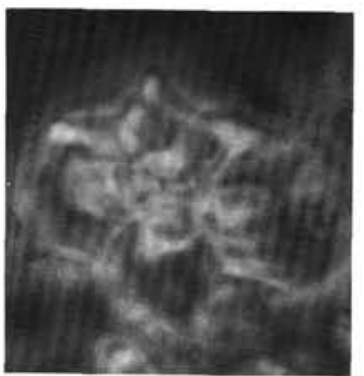

3

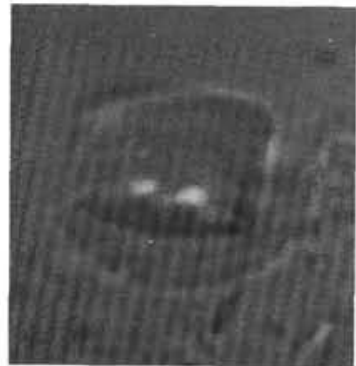

5

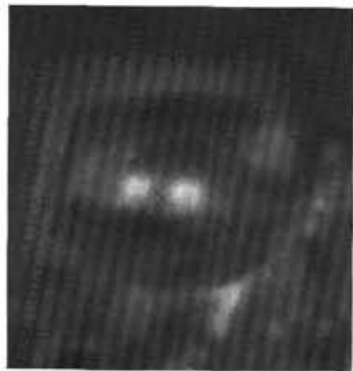

7

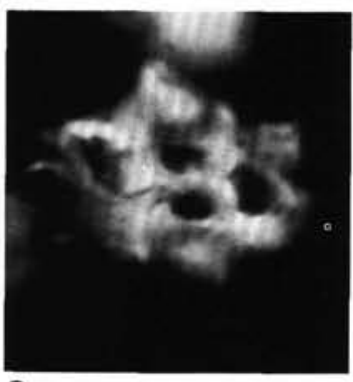

2
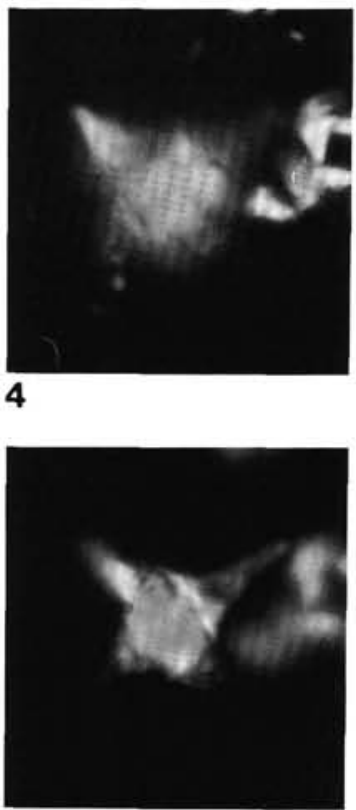

6

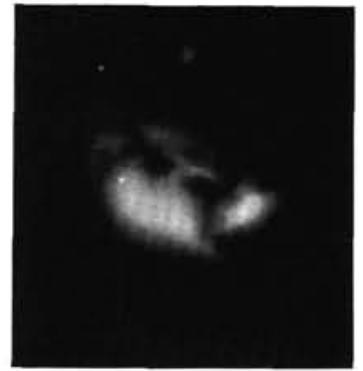

8

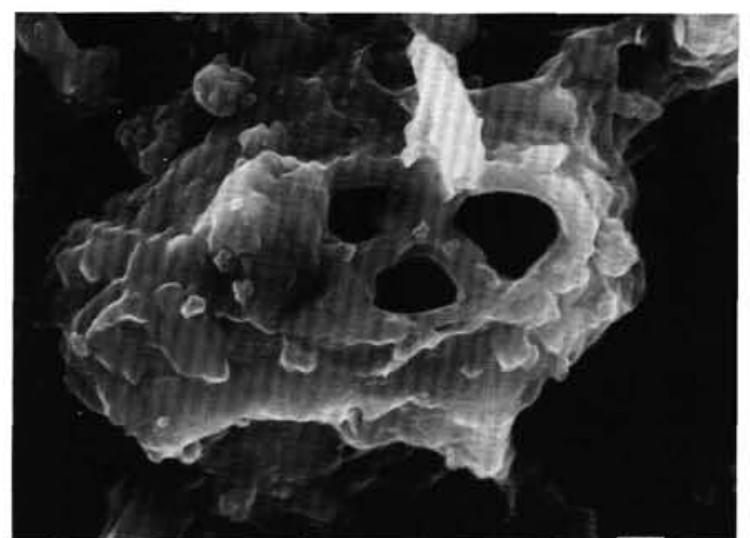

9

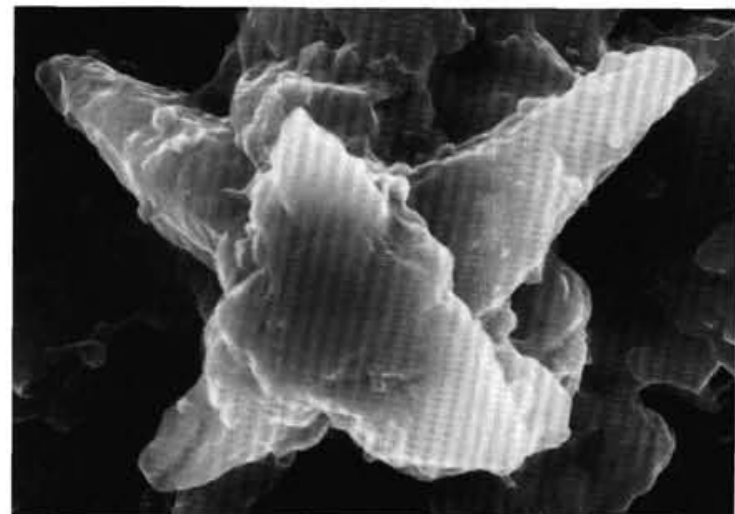

10

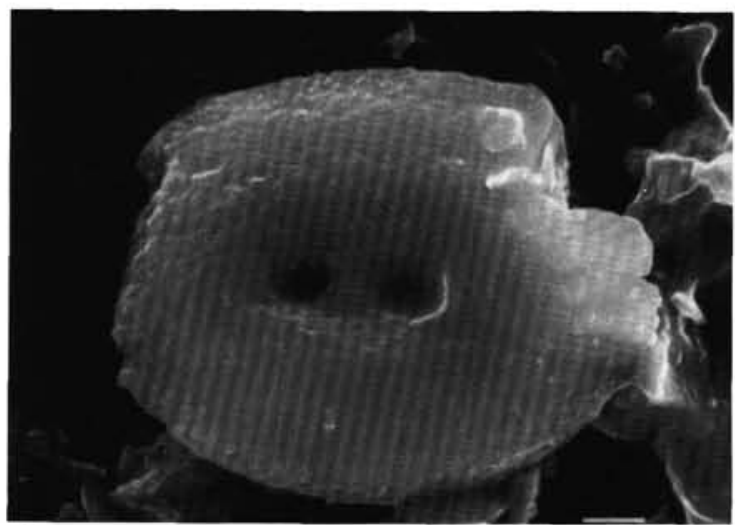

11

Plate 5. Light and SEM micrograph correlations of the same specimens. White bars in lower right corners of SEM photos represent $1 \mu \mathrm{m} . \quad 1-3,9$. Chiphragmalithus armatus, Sample 105-647A-66R-2, 49-51 cm, (1-3: 2400X; 9: 5000X). 4, 6, and 10. Imperiaster obscurus, Sample 105-647A-66R$2,49-51 \mathrm{~cm},(4,6: 1780 \mathrm{X} ; 10: 5000 \mathrm{X}) . \quad 5,7$ and 8, and 11. Helicosphaera sp. cf. H. orientalis, Sample 105-647A-21R-1, 67-69 cm, (5, 7 and 8: 2670X; 11: 6500X). 